\title{
Comparative analysis of the innovation system of Kazakhstan:
}

\section{Applying the European Innovation Scoreboard}

\begin{abstract}
Ainur Shakenova
In the modern world, economic growth is closely linked to the development of innovation. Today, to become an economically developed country, it is necessary to invest in innovation and improve factors that have a direct impact on innovation activity. However, the significant problem in innovation is the gap among the industrialized countries, countries with economies in transition, and developing countries. This study focuses on a country with a transition economy - Kazakhstan, and its ability to make an innovation breakthrough. In search of the indicators influencing innovation activity in Kazakhstan, we drew on the methodology of the European Innovation Scoreboard. Through data harmonization, we found Kazakh indicators and compared them with European indicators. This empirical result allows us to draw conclusions on the importance of human resources in science, and of fast-growing enterprises with innovation activity. The growth in $R \& D$ expenditure also positively affected Kazakh innovation in line with world practice. In this way, the quality improvement of some key factors is positively affecting the growth of many innovative indicators in Kazakhstan. The contribution of this empirical result allowed us to compare Kazakhstan with European Union countries through the European system of innovation estimation.
\end{abstract}

Keywords: Innovation gap, Kazakhstan, European Innovation Scoreboard, comparable analysis

\section{Introduction}

Technological progress and movement forward have always been a natural development in society. The blossoming of inventive evolution encouraged technological growth during the Enlightenment (Hesse 2002). In the eighteenth century, Adam Smith wrote in his work about the division of labor and the widening of the market as the main factors in encouraging technological innovation (Landes 2015). Since the time of Schumpeterian theory about innovation, the world has started building capacity in the field of technology and gained vast productivity.

At the present time, Industrial countries invest in innovation and reduce technological catch-up between upper-tier countries. While developing countries seek to catch up in the innovativeness of mid-tier countries, and start with technologies necessary for local society. The technological competition has reached fever pitch for some countries. Gradually the gap between countries began to widen by dividing the world according to economic and innovation development. Despite this gap, some EU countries have reached significant results in innovation and technology development for decades: Slovenia (Bučar 2005, Koschatzky et al. 2011, Markič et al. 2011, Likar et al. 2014) Estonia (Linnas 2008, Nauwelaers et al. 2013, Karo-Looga 2016), Czech Republic (Uzagalieva et al. 2012, Krasniqi-Kutllovci 2008), Hungary (Havas 2002, Varga 2006, Lengyel-Leydesdorff 2011, Lukovics et al. 2017), and others. Evaluating the level of innovativeness of EU countries is possible thanks to the Global Innovation 
Index (GII), the European Innovation Scoreboard (EIS), and so on. World results in innovation are published at the GII for approximately 130 countries. Global Innovation Index includes near 80 indicators with various parameters. In this paper, we chose EIS as the basis of our calculations. The EIS has a huge impact on the practitioners and theoretical specialists of EU countries by forming innovation indicators in Europe. However, the main benefit of EIS is a focus on EU countries and their indicators in innovation. The EIS measures average performance in 27 indicators in 10 innovation dimensions for EU countries. In the interest of spreading the effectiveness of indicators and their comparable strength in the Eurasian continent, the developers of EIS included several non-European countries in the list. Certainly, every country has its own approach in the calculation of innovation performance, including Kazakhstan. In this paper, we take EIS as the basis of our calculations. This article is an attempt at a comparative analysis of Kazakhstan data with EU indicators on the basis of EIS. This article helps to understand the strength and weaknesses of innovation indicators in Kazakhstan. Whereas the development and promotion of innovation is rather a fresh and current topic in Kazakhstan, we used the data of one decade to identify any progress in the indicators.

The main purpose of this research is the harmonization of Kazakhstan data with the EIS. We intend to determine if Kazakhstan data can be comparable with the EIS indicators. The indicators for calculating innovation in some countries is a long process started from gathering data and continue with data processing. To ensure that indicators can effectively interconnect with data from other countries, a close examination of what indicators do is very much needed (Iizuka-Hollanders 2020). This stage involved several steps before we reached results. The research question for this paper hence was how to harmonize Kazakh data with the EIS? This step required an explicit understanding of methodological stages and an explanation of indicators. The second part of the article includes the results and discussion in which we explained the state of innovation in 2008 and 2018.

This paper is organized as follows: section 1 describes differences in structuring innovation between developed and developing countries. The main focus of the literature review was on innovation in developing countries; section 2 introduces the origins of the data, the explanation of indicators and methodology in detail; section 3 then combines the results of the calculation to determine if the calculation of Kazakh data was in fact harmonized with EIS; section 4 describes the discussion of harmonized data; and finally, section 5 presents our conclusions.

\section{Literature review}

There is a variety of opinions about the division of countries into certain categories in the fields of economics and innovation. We have chosen the EU concept that is close to our study and subdivide countries into 4 groups: Innovation Leaders, Strong Innovators, Moderate Innovators, and Modest Innovators. The possibility of transition from one group to another was smoothly carried out over decades. During the chosen decade a significant number of countries reduced the gap from one stage to another in the EIS from 2008 to 2018. 
The transition to a new innovative stage takes on average about 10 years according to our observation. Hungary, Lithuania, Latvia, Malta, Poland, Slovakia, and Turkey have been promoted from Modest to Moderate innovative countries since 2008. By 2018, Slovenia and Norway had reached a new stage as Strong Innovators and Netherlands - Innovation Leaders.

However, most of these countries are countries with transition economies. What happens with developing countries? How should they bring down expanding lag?

The measurement and understanding of innovation has been essentially constrained by the lack of comparable and reliable data in developing countries outside of the EU (Rahayu-Day 2015, Cirera-Muzi 2020).

Moreover, the problem of bridging the rupture between the Third and the Industrialized countries has always been regarded by scientists. Paulo Antônio Zawislak with Luciana Manhães Marins (2007) proposed a new idea at the microeconomic level for innovation - a total innovation management system for firms through the structuring of innovation management activity in the reality of developing countries' firms. The scientists used traditional indicators: investment, intellectual property, and non-conventional indicators such as cadence and project mix. Thus, they showed the importance of supporting SMEs in innovative activity for countries with a low level of innovation.

Years later, the topic of entrepreneurship in innovation was also raised by researchers Adam Szirmai, Wim Naudé, and Micheline Goedhuys (2011). They considered that the policy and institutional environment is an important determinant of innovative behaviour in developing countries. However, they highlighted that the extent of entrepreneur innovativeness depends on the characteristics of the entrepreneur and the sector in which the firm is active (Szirmai et al. 2011).

Nowadays, the quantity of sources with regard to the firm-level in developing countries is widening. It includes not only the impact of firms on economic development in the country but also examines firm characteristics, its economic performance, business strategies, and opportunity for innovativeness (Goedhuys et al. 2008, Goedhuys-Sleuwaegen 2010).

Furthermore, Bronwyn Hall, Francesca Lotti, and Jacques Mairesse (2013) and Michael Polder, George van Leeuwen, Pierre Mohnen, Wladimir Raymond (2009) researched the impact on R\&D and ICT investment on innovation and productivity. The main findings showed that the basic role for innovation is assumed by R\&D investment, while for productivity - ICT investment. Thus, the impact of $\mathrm{R} \& \mathrm{D}$ on innovation is significant.

More recently, a group of scientists analyzed the effect of competition on technological innovation in developing countries through the Boone index. Their findings reveal a negative and robust impact of competition on innovation (Alvarez et al. 2015). Later, Roberto Alvarez (2016) found that for the service industry it works vice versa, R\&D impact not being as significant as ICT investment.

Vijay Govindarajan with Chris Trimble (2012) put forward five gaps between developing and developed economies: performance gap; infrastructure gap; sustainability gap; regulatory gap; preferences gap. However, in 2017 the concept of inclusive innovation was discussed, and providing a framework of four key 
dimensions (people, activities, outcomes, and governance) to consider in its implementation (Schillo-Robinson 2017).

Despite an increasing number of scientific papers about developing countries in innovation, there is not enough empirical evidence about Kazakhstan and the Central Asian region. Most articles discuss developing countries in the EU and Latin America. During the collection of Kazakh data, we noticed a relatively small number of Kazakh scientific articles with empirical results. Over two decades, the evolution of indicators impacting on innovation in Central Asia had increased modestly, but did not provide sufficient innovation growth in comparison with Europe (Table 1).

Table 1 Selected Sustainable Development Goals (SDG) Indicators in Central Asia and Europe, averages, 2000-2016

\begin{tabular}{|c|c|c|c|c|c|c|c|c|}
\hline \multirow[t]{2}{*}{ SDG Indicator } & \multicolumn{4}{|c|}{ Central Asia } & \multicolumn{4}{|c|}{ Europe } \\
\hline & 2000 & 2005 & 2010 & 2016 & 2000 & 2005 & 2010 & 2016 \\
\hline $\begin{array}{l}\text { Adjusted net } \\
\text { enrolment rate }(\%)\end{array}$ & $\cdots$ & 68.4 & 73.0 & 78.5 & 92.0 & 90.8 & 93.9 & 94.6 \\
\hline $\begin{array}{l}\mathrm{R} \& \mathrm{D} \text { expenditure as } \\
\text { a proportion of GDP } \\
(\%)\end{array}$ & 0.18 & 0.25 & 0.16 & 0.18 & 1.62 & 1.60 & 1.75 & 1.83 \\
\hline $\begin{array}{l}\text { Researchers (in full- } \\
\text { time equivalent) per } \\
\text { million inhabitants }\end{array}$ & 337.4 & 363.2 & 391.2 & 500.0 & 2458.0 & 2730.3 & 2985.7 & 3181.1 \\
\hline $\begin{array}{l}\text { Proportion of the } \\
\text { population covered } \\
\text { by at least a } 2 \mathrm{G} \\
\text { mobile network }(\%)\end{array}$ & 30.0 & 60.2 & 86.7 & 97.5 & 94.3 & 98.5 & 98.3 & 97.2 \\
\hline
\end{tabular}

Source: Global and regional data for Sustainable Development Goal Indicators, 2017 session, 28 July 2016-27 July 2017, Agenda items 5, 6 and 18 (a) (UN document E/2017/66)

We concentrated on the articles concerned with the Kazakh innovation system for two decades. Kazakhstan's economy has shown remarkable growth over the decades in Central Asia. The significant increase in GDP from USD 18.292 billion (2000) to USD 179.34 billion (2018) stands comparison to other Central Asian countries. From 2000 until 2018, the GDP indicators of the Kyrgyz Republic and Tajikistan had approximately similar values, near USD 8.093 billion and USD 7.523 billion in 2018. The GDP growth of Uzbekistan showed a significant increase, and reached near USD 50.5 billion in 2018. The GDP indicator of Afghanistan and Turkmenistan reflected similar development until 2005. At the end of 2018, Turkmenistan's GDP demonstrated a noticeable rise and achieved the result approximating the GDP of Uzbekistan. In 2018 Afghanistan also showed GDP growth, approaching USD 19.4 billion (Figure 1). 
Figure 1 GDP of Central Asian countries from 2000 to 2018 (USD, billion)

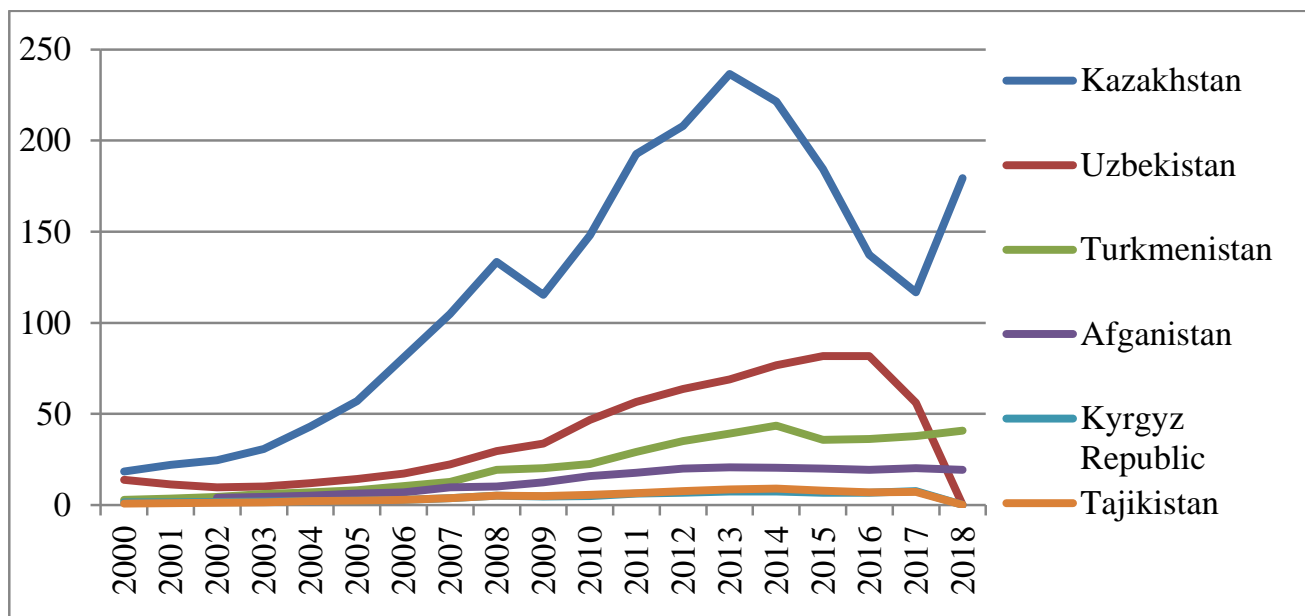

Source: own construction based on World Bank data (2000-2018)

Innovation problems in Kazakhstan and related topics have often been discussed by Kazakh researchers over the last two decades. Some Kazakh researchers have worked towards a descriptive basis for national innovation policy and strategy. Certainly, most of these works are unconvincing due to the limited number of scientists in this area. The main discussions have been about how to modernize economics through innovation, and how to include enterprises and society in this process (Nurlanova 1998, Doskaliyeva-Orynbassarova 2016). The main body of descriptive articles studied technology and innovation through branding and methods of investment appraisal taking into account both commercial and tax requirements (Nurlanova 1998, Tulegenova 2007); investment regulation mechanism with development of venture capital (Doskaliyeva-Orynbassarova 2016); the importance of ICT development for realization innovation projects (Utepbergenov et al. 2018), and so on.

In the study of Kazakh scientific articles, a number of articles are devoted to the development, the interaction, and impact of R\&D on innovation, science, and intellectual property rights in Kazakhstan. The general topics are connected with the scientific sphere where the main issues are investment in R\&D (Kurmanov et al. 2016, Ziyadin et al. 2018, Shaikin-Estes 2018), quality of scientific articles (Adambekov et al. 2014), the quantity of the researchers, and interaction of science with business through intellectual property (Radosevic-Myrzakhmet 2006, Abazov and Salimov 2016). Certainly, most of these scientists noted the importance of R\&D in the innovation process. In comparison with the EU countries, the amount of R\&D expenditure in Kazakhstan was low over the last decade. For instance, the average amount of R\&D expenditure in Europe was near 1.75 in 2010, whereas in Central Asia it was 0.16. In Kazakhstan, specifically, this indicator equalled 0.153 in 2010. 
Table 2 R\&D indicators in Kazakhstan (2010-2018)

\begin{tabular}{lccccc}
\hline Indicators & $\mathbf{2 0 1 0}$ & $\mathbf{2 0 1 2}$ & $\mathbf{2 0 1 4}$ & $\mathbf{2 0 1 6}$ & $\mathbf{2 0 1 8}$ \\
\hline GDP (billion USD) & 148.047 & 207.999 & 221.416 & 137.278 & 179.34 \\
\hline $\begin{array}{l}\text { Research and development } \\
\text { expenditure (\% of GDP) }\end{array}$ & 0.153 & 0.165 & 0.167 & 0.142 & 0.123 \\
\hline $\begin{array}{l}\text { Scientific and technical } \\
\text { journal articles }\end{array}$ & 323.91 & 445.67 & 934.97 & 1601.18 & 2367.46 \\
\hline $\begin{array}{l}\text { Researchers in R\&D (per } \\
\text { million people) }\end{array}$ & 370.533 & 612.183 & 798.665 & 693.683 & 666.935 \\
\hline $\begin{array}{l}\text { High-technology exports } \\
\text { (billion USD) }\end{array}$ & 1.813 & 3.571 & 3.396 & 2.077 & 1.784 \\
\hline
\end{tabular}

Source: own construction based on World Bank Data, 2010-2018

The development of innovation activity must also include the enhancement potentiality of regions (Cooke-Morgan 1999, Nauwelaers et al. 2013). In particular, the most high-potential regions for innovation in Kazakhstan were East Kazakhstan, Aktobe, Zhambyl, South Kazakhstan, and Mangistau regions (MukhtarovaMyltykbayeva 2015). However, according to the data of the Statistics committee in Kazakhstan, the GDP for the last 8 years had increased from USD BLN 148.047 (2010) to USD BLN 179.34 (2018). Despite this, high-technology exports remained at the same level between 2010 and 2018 (Table 2).

In practice, Kazakh scientists often refer to the world rankings occupied by Kazakhstan. When accounting for innovative activity in Kazakhstan, for example, they refer to the Global Innovation Index (Stavbunik-Pělucha 2019, Mukhammedov et al. 2019). The studies also provided comparisons between countries for certain parameters that affect innovation in general (Brunet 2012, Suyunov et al. 2018).

Typically, every country has its own calculation of innovation activity. It is impossible to say that one method can be applied to all countries. The key differences lie in each country having different innovative strategies, according to its individual ideas, resources, and possibilities. In any case, the initial data is different, the strategy is different, and the method of calculation is also different. In this study, we tried to bring Kazakhstan innovation data closer to that of European countries. The assumption of this study is that we test the possibility of transferring Kazakhstan data and overlaying it onto the EIS for 2008 and 2018 by normalization of data.

\section{Data and methodology}

The data for this empirical analysis comes from 2008 and 2018 following EIS and identifying the main variables and objects for analysis. The researched period shows how innovation developed in different countries during the decade between 2008 and 2018. The individual variables are presented for developed and developing countries in the European Union and Central Asia. Namely, we observe about 30 countries, divided into 4 groups: Innovation Leaders, Strong Innovators, Moderate Innovators, and Modest Innovators (Annex A, Table 1). This study reflects the innovation activity 
of 29 European and Central Asia countries: Austria (1), Belgium (2), Bulgaria (3), Cyprus (4), Czech Republic (5), Germany (6), Denmark (7), Estonia (8), Spain (9), Finland (10), France (11), Croatia (12), Hungary (13), Ireland (14), Italy (15), Lithuania (16), Latvia (17), Malta (18), Netherlands (19), Norway (20), Poland (21), Portugal (22), Romania (23), Sweden (24), Slovenia (25), Slovakia (26), the United Kingdom (27), Turkey (28), and Kazakhstan (29).

For determining the development of innovation activity at the European level, an aggregate indicator of innovation based on 19 indicators was used. These 19 indicators were present and defined in the EIS, except for Kazakhstan, and include: 1) New doctorate graduates per 1000 population aged 25-34 (Q1); 2) Percentage population aged 30-34 having completed tertiary education (Q2); 3) Lifelong learning of population aged from 25-64 (Q3); 4) R\&D expenditure in the public sector (\% of GDP) (Q4); 5) R\&D expenditure in the business sector (\% of GDP) (Q5); 6) NonR\&D innovation expenditure (\% of turnover) (Q6); 7) SMEs innovating in-house (\% of SMEs) (Q7); 8) Innovative SMEs collaborating with others (\% of SMEs) (Q8); 9) Public-private co-publications per million of population (Q9); 10) PCT patent applications per billion GDP (Q10); 11) Trademarks applications per billion GDP (Q11); 12) Designs applications per billion GDP (Q12); 13) SMEs introducing product or process innovations (\% of SMEs) (Q13); 14) SMEs introducing marketing or organizational innovations (\% of SMEs) (Q14); 15) Employment in fast-growing enterprises in innovative sectors (\% of total employment) $(\mathrm{Q} 15)$; 16) Employment in knowledge-intensive activities (\% of total employment) (Q16); 17) Exports of medium and high-technology products as a share of total product export (Q17); 18) Knowledge-intensive services exports as \% of total services exports (Q18); 19) Sales of new-to-market and new-to-firm innovations as \% of turnover (Q19).

These 19 indicators were divided into four main groups for a clear understanding of the roles of components in the analysis: human capital with indicators Q1, Q2, Q3; investment - Q4, Q5, Q6; innovation activity including Q7 to Q14; and innovation effect - Q15, Q16, Q17, Q18, Q19. Finally, we had 29 countries and 19 indicators. The data sources are from the EIS 2008 and 2018, World Bank, Eurostat and national statistical centers.

The methodology of transforming Kazakh statistical data for comparable analysis started with studying the differences in the statistical data. Central Asia is still in the process of development, and comparative economic research is commensurately rare (Peck 2004, Brück 2014). However, we posed ourselves this brainteaser and accounted for Kazakhstan`s data according to the EIS. Every indicator had its own capacity (load), proved by the EIS for nearly 2 decades from 2001 to recent years. We also looked at the Global Innovation Index and found the evidence basis for our research. In addition, past scientific studies give direction in choosing indicators (Hollanders-van Cruysen 2008, Schibany-Streicher 2008). During normalization, we changed the definition from "SMEs" to "enterprises" in our calculation. The next step was to find indicators for Kazakh data according to the EIS in 2008 and 2018. The main indicator components in calculating are numerator and denominator (Table 3 ). 
Table 3 Indicator components

\begin{tabular}{|c|c|c|c|}
\hline Indicator & Numerator & Denominator & Data source \\
\hline Q1 & Number of doctorate graduates & $\begin{array}{l}\text { Population between and } \\
\text { including } 25 \text { and } 34 \text { years }\end{array}$ & $\begin{array}{l}\text { World Bank data and Committee on } \\
\text { Statistics of the Republic of Kazakhstan }\end{array}$ \\
\hline Q2 & $\begin{array}{l}\text { Number of persons in age group } \\
\text { with some form of post-secondary } \\
\text { education }\end{array}$ & $\begin{array}{l}\text { Population between and } \\
\text { including } 25 \text { and } 34 \text { years }\end{array}$ & $\begin{array}{l}\text { World Bank data and Committee on } \\
\text { Statistics of the Republic of Kazakhstan }\end{array}$ \\
\hline Q3 & $\begin{array}{l}\text { Population of lifelong learning } \\
\text { statistics refers to all persons in } \\
\text { private households aged between } \\
25 \text { and } 64 \text { years }\end{array}$ & $\begin{array}{l}\text { Total population of the same } \\
\text { age group }\end{array}$ & $\begin{array}{l}\text { Analytical report on the implementation } \\
\text { of the principles of the Bologna process } \\
\text { in the Republic of Kazakhstan (2018) } \\
\text { and webpage: theglobaleconomy.com }\end{array}$ \\
\hline Q4 & $\begin{array}{l}\text { All R\&D expenditure in the } \\
\text { government sector }\end{array}$ & Gross Domestic Product & $\begin{array}{l}\text { Committee on Statistics of the Republic } \\
\text { of Kazakhstan }\end{array}$ \\
\hline Q5 & $\begin{array}{l}\text { All R\&D expenditure in the } \\
\text { business sector }\end{array}$ & Gross Domestic Product & $\begin{array}{l}\text { Committee on Statistics of the Republic } \\
\text { of Kazakhstan }\end{array}$ \\
\hline Q6 & $\begin{array}{l}\text { Sum of total innovation } \\
\text { expenditure for enterprises, } \\
\text { excluding intramural and } \\
\text { extramural R\&D expenditures }\end{array}$ & $\begin{array}{l}\text { Total turnover for all } \\
\text { enterprises }\end{array}$ & $\begin{array}{l}\text { Committee on Statistics of the Republic } \\
\text { of Kazakhstan }\end{array}$ \\
\hline Q7 & $\begin{array}{l}\text { Number of Small and medium- } \\
\text { sized enterprises (SMEs) with in- } \\
\text { house innovation activities }\end{array}$ & $\begin{array}{l}\text { Total number of Small and } \\
\text { medium-sized enterprises } \\
\text { (SMEs) }\end{array}$ & $\begin{array}{l}\text { Committee on Statistics of the Republic } \\
\text { of Kazakhstan }\end{array}$ \\
\hline Q8 & $\begin{array}{l}\text { Number of Small and medium- } \\
\text { sized enterprises (SMEs) with } \\
\text { innovation co-operation activities }\end{array}$ & $\begin{array}{l}\text { Total number of Small and } \\
\text { medium-sized enterprises } \\
\text { (SMEs) }\end{array}$ & $\begin{array}{l}\text { Committee on Statistics of the Republic } \\
\text { of Kazakhstan }\end{array}$ \\
\hline Q9 & $\begin{array}{l}\text { Number of public-private co- } \\
\text { authored research publications }\end{array}$ & Total population & $\begin{array}{l}\text { Committee on Statistics of the Republic } \\
\text { of Kazakhstan }\end{array}$ \\
\hline Q10 & Number of patent applications & $\begin{array}{l}\text { Gross Domestic Product in } \\
\text { Purchasing Power Standard }\end{array}$ & $\begin{array}{l}\text { National Patent Office in Kazakhstan } \\
\text { and Committee on Statistics of the } \\
\text { Republic of Kazakhstan }\end{array}$ \\
\hline Q11 & $\begin{array}{l}\text { Number of trademark applications } \\
\text { applied }\end{array}$ & $\begin{array}{l}\text { Gross Domestic Product in } \\
\text { Purchasing Power Standard }\end{array}$ & $\begin{array}{l}\text { National Patent Office in Kazakhstan } \\
\text { and Committee on Statistics of the } \\
\text { Republic of Kazakhstan }\end{array}$ \\
\hline Q12 & $\begin{array}{l}\text { Number of individual designs } \\
\text { applied }\end{array}$ & $\begin{array}{l}\text { Gross Domestic Product in } \\
\text { Purchasing Power Standard }\end{array}$ & $\begin{array}{l}\text { National Patent Office in Kazakhstan } \\
\text { and Committee on Statistics of the } \\
\text { Republic of Kazakhstan }\end{array}$ \\
\hline Q13 & $\begin{array}{l}\text { Number of Small and medium- } \\
\text { sized enterprises (SMEs) who } \\
\text { introduced at least one product } \\
\text { innovation or process innovation } \\
\text { either new to the enterprise or new } \\
\text { to their market }\end{array}$ & $\begin{array}{l}\text { Total number of Small and } \\
\text { medium-sized enterprises } \\
\text { (SMEs) }\end{array}$ & $\begin{array}{l}\text { Committee on Statistics of the Republic } \\
\text { of Kazakhstan }\end{array}$ \\
\hline Q14 & $\begin{array}{l}\text { Number of Small and medium- } \\
\text { sized enterprises (SMEs) who } \\
\text { introduced at least one new } \\
\text { organizational innovation or } \\
\text { marketing innovation }\end{array}$ & $\begin{array}{l}\text { Total number of Small and } \\
\text { medium-sized enterprises } \\
\text { (SMEs) }\end{array}$ & $\begin{array}{l}\text { Committee on Statistics of the Republic } \\
\text { of Kazakhstan }\end{array}$ \\
\hline Q15 & $\begin{array}{l}\text { Number of employees in high- } \\
\text { growth enterprises in } 50 \% \text { 'most } \\
\text { innovative' industries }\end{array}$ & $\begin{array}{l}\text { Total employment for } \\
\text { enterprises with } 10 \text { or more } \\
\text { employees }\end{array}$ & $\begin{array}{l}\text { Committee on Statistics of the Republic } \\
\text { of Kazakhstan }\end{array}$ \\
\hline Q16 & $\begin{array}{l}\text { Number of employed persons in } \\
\text { knowledge-intensive activities in } \\
\text { business industries }\end{array}$ & Total employment & $\begin{array}{l}\text { Committee on Statistics of the Republic } \\
\text { of Kazakhstan }\end{array}$ \\
\hline Q17 & $\begin{array}{l}\text { Value of medium and high tech } \\
\text { exports }\end{array}$ & $\begin{array}{l}\text { Value of total product } \\
\text { exports }\end{array}$ & $\begin{array}{l}\text { Committee on Statistics of the Republic } \\
\text { of Kazakhstan }\end{array}$ \\
\hline Q18 & $\begin{array}{l}\text { Exports of knowledge-intensive } \\
\text { services }\end{array}$ & $\begin{array}{l}\text { Total value of services } \\
\text { exports }\end{array}$ & $\begin{array}{l}\text { Committee on Statistics of the Republic } \\
\text { of Kazakhstan }\end{array}$ \\
\hline Q19 & $\begin{array}{l}\text { Sum of total turnover of new or } \\
\text { significantly improved products, } \\
\text { either new-to-the-firm or new-to- } \\
\text { the-market, for all enterprises }\end{array}$ & $\begin{array}{l}\text { Total turnover for all } \\
\text { enterprises }\end{array}$ & $\begin{array}{l}\text { Committee on Statistics of the Republic } \\
\text { of Kazakhstan }\end{array}$ \\
\hline
\end{tabular}

Source: own construction 
During the normalization of data, we chose eight years: 2001-2009 and 2010 2018. We replaced close to $20 \%$ of absent data with previous or subsequent years. The main idea of the EIS lay based on normalization data among comparable countries. However, before reaching the normalization of Kazakh data, indicators and denominators need to be calculated. The next steps in harmonizing data, according to the EIS are a) identifying and replacing outliers, setting reference years, b) importing for missing values, c) determining Maximum and Minimum scores, d) transforming data that have highly skewed distributions across countries, e) calculating re-scaled scores, f) calculating composite innovation indexes, g) calculating relative-to-EU performance scores.

The first sub-step for calculating Kazakhstan indicators was identifying positive and negative outliers. The positive/negative outliers were identified as the country scores which were higher/lower than the mean across all countries plus/minus twice the standard deviation. The replacement of outliers was carried out by maximum and minimum values over all the years studied. The next sub-step included the second and third sub-steps together. The setting of reference years was conducted on the basis of data availability for Kazakhstan, specifically, where it was at least $75 \%$ complete. In practice, the reference year is one or two years behind the year in which the performance of a score is measured. The data of reference years replaces the value for the previous year. The replacement of missing data in the time series is carried out using the next available year according to the EIS. The Maximum/Minimum scores was determined as the highest score and, similarly, the lowest score for the last eight years in Kazakhstan, excluding positive/negative outliers. In the middle of the normalization process, the data required transformation. The data, which was skewed for eight years, was transformed using a square root transformation. This sub-step meant using the square root of the indicator value instead of the original value. In doing so, we decreased volatile and skewed data distributions.

A possible transformation of the data leads to rescaled scores by subtracting the Minimum score and then dividing by the difference between the Maximum and Minimum score. The maximum rescaled score is thus equal to 1 , and the minimum rescaled score is equal to 0 . For positive and negative outliers, the rescaled score is equal to 1 or 0, respectively, according to the EIS 2018.

The calculation of a Summary Innovation Index is the unweighted average of the rescaled scores for all indicators where all indicators receive the same weight. The final step in the normalization of data comes to calculating relative-to-EU performance scores. This score calculates as the SII of the respective country divided by the SII of the EU multiplied by 100 .

The detailed explanation of these steps are to be found in the Report of the EIS 2008 and 2018.

\section{Results and discussion}

The main result that we achieved through research proved our hypothesis on the possibility of the normalization of Kazakh data according to the EIS (Table 4). The findings refer only to Kazakh data because the data of other European countries were normalized and reported in the EIS 2008 and 2018. 
Table 4 Normalization of Kazakhstan data according to EUIS 2008, 2018

\begin{tabular}{cccccc}
\hline Indicator & $\mathbf{2 0 0 8}$ & $\mathbf{2 0 1 8}$ & Indicator & $\mathbf{2 0 0 8}$ & $\mathbf{2 0 1 8}$ \\
\hline Q1 & 0.07 & 0.3 & Q11 & 22.6 & 29.2 \\
Q2 & 22.7 & 53.98 & Q12 & 1.1 & 1.1 \\
Q3 & 1 & 1.1 & Q13 & 2.4 & 6.6 \\
Q4 & 0.22 & 0.25 & Q14 & 0.8 & 10.5 \\
Q5 & 0.23 & 0.1 & Q15 & 0.2 & 2.3 \\
Q6 & 0.002 & 0.37 & Q16 & 8.7 & 10.3 \\
Q7 & 3.1 & 36.6 & Q17 & 20.2 & 17.3 \\
Q8 & 3.3 & 36.8 & Q18 & 5.94 & 3.5 \\
Q9 & 1.6 & 5.9 & Q19 & 17 & 32.7 \\
Q10 & 11.3 & 7.1 & & & \\
\hline
\end{tabular}

Source: own construction

The first group of indicators showed low values after the normalization of Kazakh data, except the indicator Q2. This indicator was at a fairly high level in comparison with other European countries. The indicators of the second group illustrated sustainable R\&D expenditures only in the public sector whereas the other two improved their rates but not significantly. The most substantial and important group of indicators showed the activity in innovation through intellectual property and companies involved in the process. The results of the involvement of Kazakh companies in innovative production indicated poor underlying progress. Besides that, the evaluation of the level of intellectual property was found in the different significance of figures in 2 comparable years. The result considered in the context of each year individually revealed the growth of intellectual property in Kazakhstan in 2018. At the end of 2018, the last group of indicators also demonstrated growth in comparison with the previous decade (Annex C, Tables 1 and 2).

The group of first three indicators connected closely with human resources (Q1, Q2, Q3). The importance of human resources in economics (Agiomirgianakis et al. 2002, Dakhli-Clercq 2004, Kato et al. 2015, Bohdan 2019, McDonald 2019) and innovation (Gupta 1993, Sternberg-Lubart 1999, Acs 2005, Blaga-Jozsef 2014, McKeown 2019) cannot be underestimated. Despite rapidly increasing robotization and automatization, human capital plays a major role and remains a driving force of economic growth (Iosif 2014, Grodzicki 2018, Faggian et al. 2019). The micro-level of the economics shows the dependence of firm performance and ability for innovative activity on human resources through empirical results: in the USA (Coleman 2007, Marvel-Lumpkin 2007, Sullivan-Marvel 2011, Tang-Murphy 2012), in Italy (Colombo-Grilli 2005), in Belgium (De Winne-Sels 2010), in the UK (Ganotakis 2012), in Israel (Gimmon-Levie 2010), in China (Huang et al. 2012), in Germany (Rauch-Rijsdijk 2013), and in Japan (Kato et al. 2015).

The level of tertiary education in the country also plays a major role in shaping economic activity, the development of society, and SMEs. It is a start for continuing to the next phase of full-education, and is given by our first indicator (the number of 
doctorates). Indeed, the population of people with tertiary diploma forms the middle and higher classes in the country (Easterly 1999). Tertiary education has a more positive impact than secondary education (Agiomirgianakis et al. 2002). At the same time, we didn`t find a significant impact of tertiary education on innovation (Annex B, Figure 1). We surmise that the growth of population with completed tertiary education aged 30-34 impacts more on internal processes without direct proximity to innovation. Specifically, no dependence of the influences of tertiary education growth on the country's transition from one stage of innovation development to stronger countries was observed.

The level of highly-educated people in a country imposes conditions of growth in science and technology in the long-run (Grodzicki 2000, Duru-BellatGajdos 2012, Bogoviz 2019). Thus, the result of the first indicator illustrated progressive growth during the decade for most countries studied. Only one country saw this indicator decreasing slightly from 0.86 to 0.6 at the end of 2018 - in Poland. In the comparison between 2008 and 2018, the first indicator (Q1) grew significantly from 0.07 to 0.3 in Kazakhstan (Table 4). We found that the higher the number of doctoral graduates indicator, the higher the innovation activity in the country (Figure 2). Thus, we would like to note that the number of doctorates has to be increased by attracting young people to science, by paying competitive salaries, improving laboratories and conditions for research, and raising the prestige of scientists, etc.

Figure 2 Indicator Q1 - New doctoral graduates per 1,000 population aged 25-34

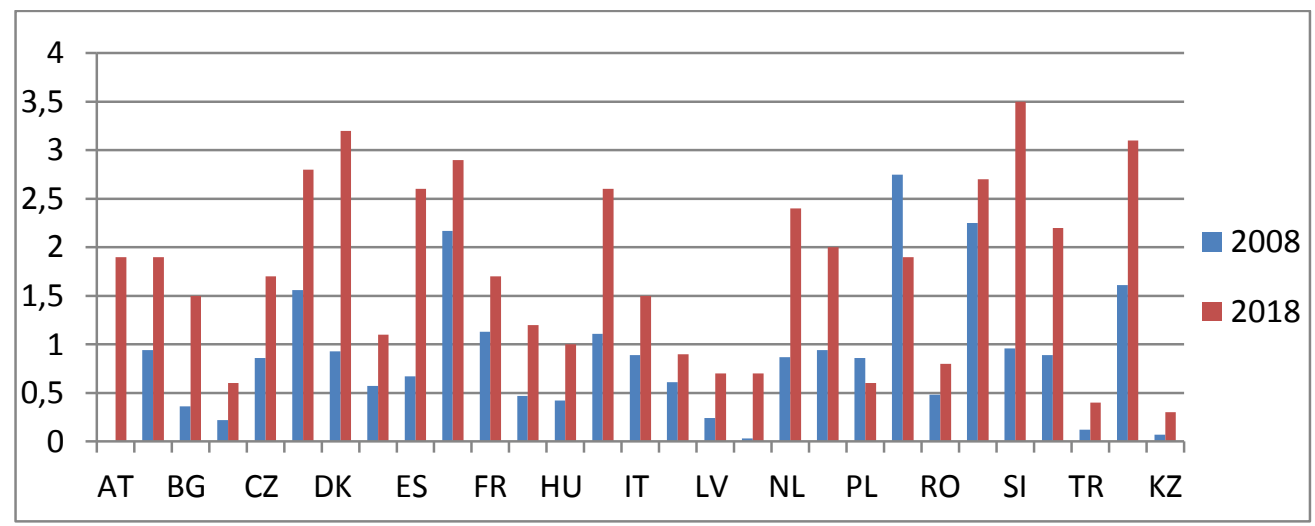

Source: own construction

Education and skill improvement became a continuing process in the Digital Age (Fischer 2000, Fischer-Konomi 2007, Sahlberg 2009). Indicator Q3 illustrated lifelong learning in European countries, and in Kazakhstan that calculated as all persons in private households aged between 25 and 64 years, according to EIS 2018. The multifaceted approach to lifelong learning statistics in different countries showed some ambiguity for this indicator in Kazakhstan. However, we found some statistics pertaining to lifelong learning. Thus, in the process of normalizing Kazakh data, we arrived at the result of 1.0 for 2008 and of 1.1 for 2018 (Annex B, Figure 2). Moreover, it was the lower mark among European Union countries for lifelong learning. However, the approaches in collecting data were different - in European countries, it 
was by questionnaire, while Kazakh data was collected through the report. We are convinced there is a higher degree of lifelong learning in the population of Kazakhstan through practical experience.

The second group of indicators highlight investment (Q4, Q5, and Q6). Finance is an important part of the commercialization process (Nickell-Nicolitsas 1997). Through research, we found that investment has a positive impact on innovation (Popov-Roosenboom 2009). Further, the integration between innovation and R\&D showed a positive relationship in empirical results (Pegkas et al. 2019).

In Kazakhstan, R\&D expenditure in the public sector (\% of GDP) (Q4) in 2008 was 22.2 and grew slightly in 2018 - 22.5 (Figure 3). The indicator Q5 reflected business expenditure in R\&D. R\&D expenditure in the private sector was 0.3 in 2008 and tripled in $2018-0.10$ (Annex B, Figure 3). The last indicator in this group was the indicator of non-R\&D innovation expenditure excluding intramural and extramural $\mathrm{R} \& \mathrm{D}$ expenditure. This indicator measures non-R\&D innovation expenditure as a percentage of total turnover (Report of EUIS 2018). The rate was 0.002 (2008) and 0.37 (2018) in Kazakhstan (Annex B, Figure 4). Ostensibly, this indicator showed significant growth in 2018 compared with 2008. Measured in the national currency, these 3 indicators always grew. In fact, growth was poor due to the difference in the exchange rate of foreign currencies to the national currency (KZT). Namely, from 2008 to 2018, the foreign rate to tenge (KZT) doubled and lead to significant fluctuation in the national currency and declining values in the case of some q-indicators dependent on foreign currency in 2018. Countries with high involvement in innovation have an indicator of R\&D expenditures upwards of 0.6 , according to the EIS. While countries with transition economies show performance from 0.5 to 0.2 . indicator value of less than 0.2 is characteristic of the modest group of innovators (Figure 3). Thus, the improvement of R\&D expenditure indicators will have produce significant growth in Kazakh innovation.

Figure 3 Indicator Q4 - R\&D expenditure in the public sector (\% of GDP)

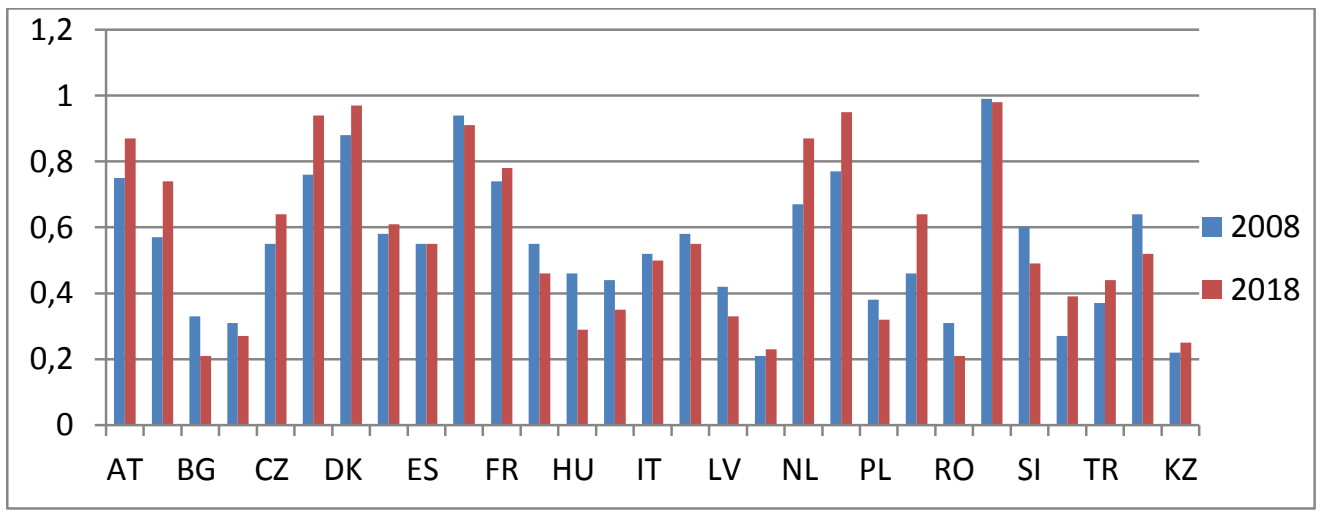

Source: own construction

Unfortunately, due to the limited data about venture capital, we excluded the calculation of this indicator. Moreover, according to the Law in Kazakhstan, the understanding of venture capital is blurred and such capital is usually provided by the 
government. Certainly, private venture capital also exists in the Kazakhstan innovation market but as a low proportion. The development of R\&D by strong financial support and the availability of venture capital at the stage of a start-up is recommended for progress in innovation. The potential for innovative activity of the enterprise is sown through resources such as human capital, intellectual property, investment, and state support of innovative projects, and depends on many other factors. Importantly, the companies have to be interested in the invention and production of new products needed by society in the present time. In the innovation activity part of the analysis, we included indicators of innovation enterprises, intellectual property, and other assets. In general, we were able to point to positive results in 2018 in comparison with a decade ago.

In the table of the EIS, the indicators reflected an underestimated average value in comparison with highly developed innovative countries. However, at the level of the countries with a transition economy, Kazakh indicators showed a stable rise in the potential development of innovative activity in the country.

The world crisis of 2008 produced the collapse of the financial sphere and led to difficulties in innovation too. Kazakhstan's economy also suffered during the crisis. At that time, the economy was in a precarious position, which probably contributed to the revision of innovation strategy in Kazakhstan.

The level of development of companies that have introduced any new or significantly improved products or production processes after 2008 improved to 36.6 in 2018 (Annex B, Figure 5). The indicator of co-operation Kazakh enterprises grew significantly from 3.3 to 36.8 in 2018 (Annex B, Figure 6). This indicator illustrated the enormous dependence of Kazakh enterprises on external interconnections. Thus, output demonstrated that Kazakh companies need to build the strong potential of human resources and equipment. There also remain strategically important challenges for the innovative development of Kazakhstan in the future. Naturally, enterprises have to support contacts and co-operate with other firms during the innovation process, but this indicator should be at the average or less level than in 2018.

The position of Kazakhstan in terms of the number of public-private coauthored research publications (Q9) has borne out the problems discussed in this article. Low results for the indicator (less than 6) are shown by several countries: Bulgaria, Lithuania, Latvia, Malta, Poland, Romania, Turkey, and Kazakhstan (Annex B, Figure 7). The indicator Q9 correlated significantly with indicator Q1 - number of doctorate graduates (Figure 2).

The indicators Q10 (Figure 4, 5), Q11, Q12 (Annex B, Figure 8, 9) indicate the development of the intellectual property in Kazakhstan. During 27 years of independence, Kazakhstan continues improving its intellectual property system from year to year. The significant growth of patent and trademark applications has led to increased interest from business and government. Public awareness of intellectual property protection remains at a low level, but the number of applicants is increasing every year, indicating that the dissemination of information about the need for registration the future intellectual capital (Figure 4, 5) has been effective. 
Figure 4 Indicator Q10 - PCT patent applications per billion GDP in 2008

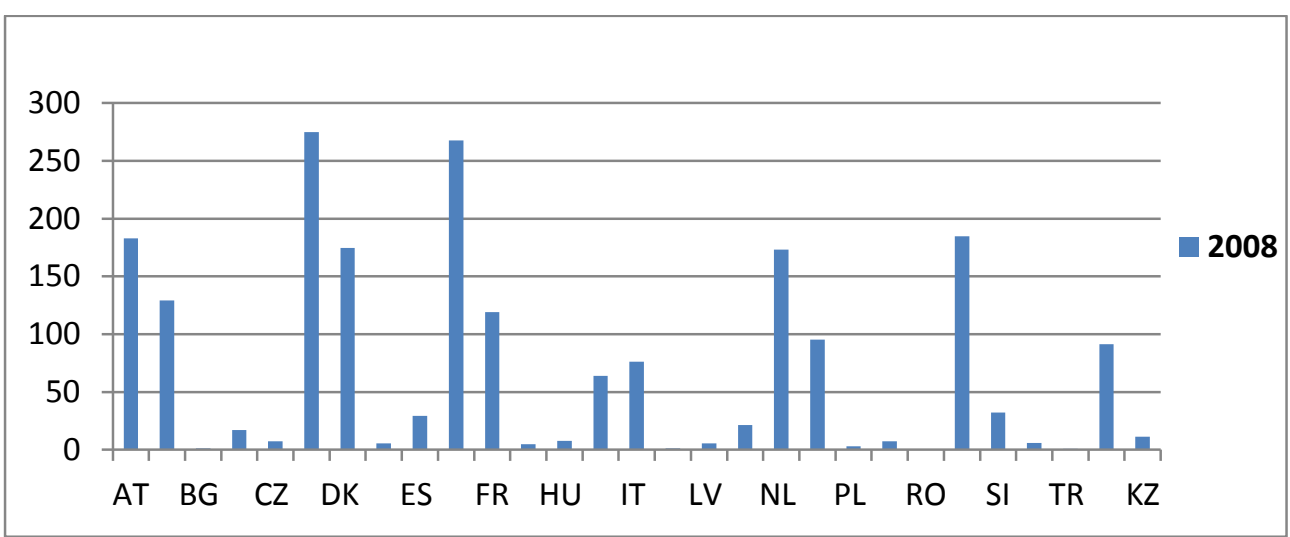

Source: own construction

Figure 5 Indicator Q10 - PCT patent applications per billion GDP in 2018

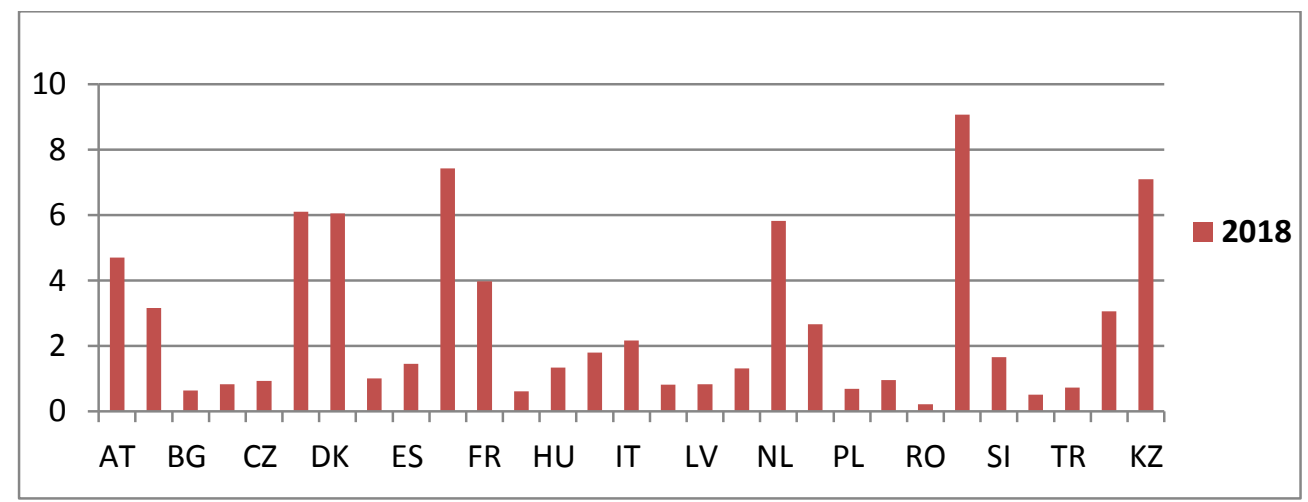

Source: own construction

In 2018 SMEs introducing product or process innovations and SMEs introducing marketing or organizational innovations grew significantly in comparison with 2008. However, in comparison with EU countries, Kazakhstan reached the level of a few moderate innovator countries in 2018 (Annex B, Figure 10, 11).

The indicators of employment in fast-growing enterprises in Kazakhstan matched those of strong innovator countries: Austria, Finland, and Belgium with similar growth in 2018 (Annex B, Figure 12, 13). However, with the same level of employment in fast-growing enterprises in Austria, Finland, Belgium, and Kazakhstan, the difference in the indicator of exports of medium and high-tech products in Kazakhstan was less than twofold (Annex B, Figure 14).

Due to the limited scope of this article, we would like to identify future directions for exploring the impact of the employment rate in fast-growing companies on the exports of medium and high-tech products in Europe and Central Asia. For future practical contributions, it would also be necessary to clarify exactly what factors influence indicators Q15 and Q17, and also the impact and interaction of Q18 and Q19 (Annex B, Figure 15, 16). Perhaps this will lead to subsequent in-depth discoveries in the management of innovative processes in enterprises. 


\section{Conclusion}

The ability of a country to innovate helps it stay competitive on the global market. Innovation policy defines the weaknesses and strengths of a country in innovation. Innovation strategy determines the direction in innovation, mitigates weaknesses, supports technology breakthroughs, and so on. Most developed countries are able to identify their innovation strengths, which allow them to move forward at a faster pace. For instance, the strengths of Germany in innovation are high-tech density and patent activity; for Singapore - tertiary efficiency; for Sweden - R\&D intensity; for Finland - productivity and researcher concentration. For the mitigation of weaknesses and reinforcement of strengths in innovation, developing countries need to know in detail the comparative level of their innovativeness. In this article, we normalized and calculated Kazakh data by 19 indicators according to the methodology of EIS. Thus, we answered the main question of this research. During our calculations, we found the weak spots in innovation in Kazakhstan. We surmise that the slow development of innovation depends on the lack of investment in R\&D. Moreover, we consider the impact of human resources on innovation through low values in the indicators of published articles and new doctorates to be significant. The harmonization of data allowed us to see the dependence between employment rate in fast-growing companies and the export of medium and high-tech products to Europe and Central Asia (Annex C, Table 1, 2).

In the end, we have an idea of the innovative potential Kazakhstan has on a global scale after normalizing Kazakh data. It is difficult to deny that the need for catching up in most of the indicators, which is interconnected for many of the indicators presented, will lead to a shift in the positive direction. This study showed the improvement of Kazakh indicators from Modest Innovator to Moderate Innovators country between 2008 and 2018.

\section{References}

Abazov, R. - Salimov, U. (2016): Technoparks in Kazakhstan: will they help develop the innovation sector? The Central Asia-Caucus Analysists, 2, 3, 12-15.

Acs, Z. J. (2004): Innovation and the growth of cities //Contributions to Economic Analysis. T. 266, 635-658.

Adambekov, S. - Dosmukhambetova, G. - Nygymetov, G. - LaPorte, R. - Linkov, F. (2014): Why Does Kazakhstan Need New Scientific Journals? Central Asian journal of global health, 3,1 .

Agiomirgianakis, G. - Asteriou, D. - Monastiriotis, V. (2002): Human capital and economic growth revisited: A dynamic panel data study. International advances in economic research, 8, 3, 177-187.

Alvarez, R. (2016): The impact of $R \& D$ and ICT investment on innovation and productivity in Chilean firms. Inter-American Development Bank Technical Note Series: Washignton DC, IDB-TN-1056, June.

Alvarez, R. - Bravo-Ortega, C. - Zahler, A. (2015): Innovation and productivity in services: evidence from Chile. Emerging Markets Finance and Trade, 51, 3, 593-611. 
Blaga, P. - Jozsef, B. (2014): Human resources, quality circles and innovation. Procedia Economics and Finance, 15, 1458-1462.

Bogoviz, A. V. (2019): Industry 4.0 as a new vector of growth and development of knowledge economy. In Popkova, E. G. - Ragulina, J. V. - Bogoviz, A. V. (eds.): Industry 4.0: Industrial Revolution of the 21st Century. Springer, Cham, 85-91.

Bohdan, N. (2019): Education and Science for Innovative Development of the Eurasian Economic Union Countries (Russia, Belarus, Kazakhstan, Armenia, Kyrgyzstan). Intergenerational Relations and Intergenerational Education. IntechOpen.

Brunet, F. (2012): The technique of pressure knapping in Central Asia: innovation or diffusion? In Desrosiers, P. M. (ed.): The Emergence of Pressure Blade Making. Springer, Boston, MA, 307-328.

Brück, T. - Esenaliev, D. - Kroeger, A. - Kudebayeva, A. - Mirkasimov, B. - Steiner, S. (2014): Household survey data for research on well-being and behavior in Central Asia. Journal of Comparative Economics, 42, 3, 819-835.

Bučar, M. (2005): National Innovation System in Slovenia. In Kobal, E. - Radosevic, S. (eds.): Modernisation of Science Policy and Management Approaches in Central and South East Europe, 48, 139.

Cirera, X. - Muzi, S. (2020): Measuring innovation using firm-level surveys: Evidence from developing countries. Research Policy, 49, 3, 103912.

Coleman, S. (2007): The role of human and financial capital in the profitability and growth of women- owned small firms. Journal of Small Business Management, 45, 3, 303-319.

Colombo, M. G. - Grilli, L. (2005): Founders' human capital and the growth of new technology-based firms: A competence-based view. Research policy, 34, 6. 795-816.

Dakhli, M. - De Clercq, D. (2004): Human capital, social capital, and innovation: a multi-country study. Entrepreneurship \& regional development, 16, 2, 107128.

De Winne, S. - Sels, L. (2010): Interrelationships between human capital, HRM and innovation in Belgian start-ups aiming at an innovation strategy. The International Journal of Human Resource Management, 21, 11, 1863-1883.

Doskaliyeva, B. B. - Orynbassarova, Y. D. (2016): Development of the System of Investment Support of Projects in the Industrial-Innovative Development of Kazakhstan. International Journal of Environmental and Science Education, 11, 12, 5109-5127.

Duru-Bellat, M. - Gajdos, T. (2012): Access to Higher Education: What counts as fairness in both an individual and systemic perspective?

Easterly, W. (1999): The middle class consensus and economic development. The World Bank.

Faggian, A. - Modrego, F. - McCann, P. (2019): Human capital and regional development. In Capello, R. - Nijkamp, P. (eds.): Handbook of regional growth and development theories. Edward Elgar Publishing.

Fischer, G. (2000): Lifelong learning-more than training. Journal of Interactive Learning Research, 11, 3, 265-294. 
Fischer, G. - Konomi, S. (2007): Innovative socio- technical environments in support of distributed intelligence and lifelong learning. Journal of Computer Assisted Learning, 23, 4, 338-350.

Ganotakis, P. (2012): Founders' human capital and the performance of UK new technology based firms. Small Business Economics, 39, 2, 495-515.

Gimmon, E. - Levie, J. (2010): Founder's human capital, external investment, and the survival of new high-technology ventures. Research Policy, 39, 9, 1214-1226.

Goedhuys, M. - Janz, N.- Mairesse, J. - Mohnen, P. (2008): 'Micro Evidence on Innovation and Development (MEIDE): An Introduction', The European Journal of Development Research, 20, 2, 167-171.

Goedhuys, M. -Sleuwaegen, L. (2010): 'High-growth Entrepreneurial Firms in Africa: A Quantile Regression Approach'. Small Business Economics Journal, 34, 31-51.

Cooke, P. - Morgan, K. (1999): The associational economy: firms, regions, and innovation. OUP Catalogue.

Govindarajan, V. - Trimble, C. (2012): Reverse innovation: a global growth strategy that could pre- empt disruption at home. Strategy \& Leadership.

Grodzicki, J. (2000): Edukacja czynnikiem rozwoju gospodarczego. Wydawn, Adam Marszałek.

Grodzicki, T. (2018): Human Capital as a Factor Creating Innovation in the Visegrad Countries. Икономически изследвания, 5, 27-34.

Gupta, A. K. - Singhal, A. (1993): Managing human resources for innovation and creativity. Research-Technology Management, 36, 3, 41-48.

Hall, B. H. - Lotti, F. - Mairesse, J. (2013): Evidence on the impact of R\&D and ICT investments on innovation and productivity in Italian firms. Economics of Innovation and New Technology, 22, 3, 300-328.

Havas, A. (2002): Does innovation policy matter in a transition country? The case of Hungary. Journal of International Relations and Development, 5, 4, 380-402.

Hesse, C. (2002): The rise of intellectual property, 700 BC-AD 2000: An idea in the balance. Daedalus. 131, 2, 26-45.

Hollanders, H. - van Cruysen, A. (2008): Rethinking the European innovation scoreboard: A new methodology for 2008-2010. Inno-Metrics Publication. Brüssel.

Huang, H. C. - Lai, M. C. - Lo, K. W. (2012): Do founders' own resources matter? The influence of business networks on start-up innovation and performance. Technovation, 32, 5, 316-327.

lizuka, M. - Hollanders, H. (2020): Innovation Indicators: for a critical reflection on their use in Low-and Middle-Income Countries (LMICs). National Graduate Institute for Policy Studies, 19-29.

Iosif, A. E. (2014): Innovation as a generator of national competitiveness in the European Union. The 8th International Management Conference „,Management Challenges for Sustainable Development", Bucharest, Romania, 6th-7th November.

Karo, E. - Looga, L. (2016): Understanding institutional changes in economic restructuring and innovation policies in Slovenia and Estonia. Journal of International Relations and Development, 19, 4, 500-533. 
Kato, M. - Okamuro, H. - Honjo, Y. (2015): Does Founders' Human Capital Matter for Innovation? Evidence from J apanese Startups. Journal of Small Business Management, 53, 1, 114-128.

Koschatzky, K. - Bross, U. - Stanovnik, P. (2001): Development and innovation potential in the Slovene manufacturing industry: analysis of an industrial innovation survey. Technovation, 21, 5, 311-324.

Krasniqi, B. A. - Kutllovci, E. A. (2008): Determinants of innovation: evidence from Czech Republic, Poland and Hungary. International Journal of Technoentrepreneurship, 1, 4, 378-404.

Kurmanov, N. - Turekulova, D. D. - Doskeyeva, G. - Alina, G. A (2016): A research on innovation in small and medium-sized enterprises: The case of Kazakhstan. International Journal of Economics and Financial Issues, 6, 3, 907-910.

Landes, D. S. (2015): Wealth and poverty of nations. Hachette UK.

Lengyel, B. - Leydesdorff, L. (2011): Regional innovation systems in Hungary: The failing synergy at the national level. Regional Studies, 45, 5, 677-693.

Likar, B. - Kopač, J. - Fatur P. (2014): Innovation investment and economic performance in transition economies: Evidence from Slovenia. Innovation, 16, $1,53-66$.

Linnas, R. (2008): An assessment and evaluation of innovation policy: the case of Estonia. Discussions on Estonian Economic Policy, 16, 98-118.

Lukovics, M. - Flipse, S. M. - Udvari, B. - Fisher, E. (2017): Responsible research and innovation in contrasting innovation environments: Socio-Technical Integration Research in Hungary and the Netherlands. Technology in Society, 51, 172-182.

Markič, M. - Likar, B. - Mescaron, M. - Rascaron, K. - Živković, S. (2011): Innovation policy and successfulness of micro and small companies in the Republic of Slovenia. African journal of business management, 5, 22, 95599567.

Marvel, M. R. - Lumpkin, G. T. (2007): Technology entrepreneurs' human capital and its effects on innovation radicalness. Entrepreneurship Theory and Practice, 31, 6, 807-828.

McDonald, B. D. (2019): A human capital model of the defense-growth relationship. The Social Science Journal.

McKeown, T. (2019): The role of HRM in generating Innovation \& Creativityhelping or hindering?? Journal of Management \& Organization, 25, 2, 173 174.

Mukhammedov, O. O. - Tasmaganbetov, A. B. - Tasmaganbetova S. Zh. (2019): Kazakhstan In The Ranking On The Global Innovation Index. Statistics, Accounting and Auditing, 4, 145-150.

Mukhtarova, K. - Myltykbayeva, A. (2015): Innovation Potential of Kazakhstan's Regions: Evaluation and Ways for Development. Central Asian Journal of Social Sciences and Humanities, 1, 2.

Nauwelaers, C. - Maguire, K. - Marsan, G. A. (2013): The Case of Helsinki-Tallinn (Finland-Estonia) Regions and Innovation: Collaborating Across Borders.

Nickell, S. - Nicolitsas, D. (1997): Human capital, investment and innovation: what are the connections?, pp. 20. 
Nurlanova, N. K. (1998): Formation and use of investments in the Kazakhstan's economy: strategies and mechanisms. Almaty: Gylym.

Peck, A. E. (2004): Economic development in Kazakhstan: the role of large enterprises and foreign investment. Routledge.

Pegkas, P. - Staikouras, C. - Tsamadias, C. (2019): Does research and development expenditure impact innovation? Evidence from the European Union countries. Journal of Policy Modeling, 41, 5,1005-1025.

Polder, M. - Leeuwen, G. V. - Mohnen, P. - Raymond, W. (2009): "Productivity Effects of Innovation Modes." Unpublished.

Popov, A. A. - Roosenboom, P. (2009): Does private equity investment spur innovation? Evidence from Europe.

Radosevic, S. - Myrzakhmet, M. (2006): Between vision and reality: promoting innovation through technoparks in Kazakhstan. - UCL School of Slavonic and East European Studies (SSEES), №. 66.

Rahayu, R. - Day, J. (2015): Determinant factors of e-commerce adoption by SMEs in developing country: evidence from Indonesia. Procedia-Social and Behavioral Sciences, 195,142-150.

Rauch, A. - Rijsdijk, S. A. (2013): The effects of general and specific human capital on long-term growth and failure of newly founded businesses. Entrepreneurship Theory and Practice, 37, 4, 923-941.

Sahlberg, P. (2009): Lifelong Learning. Lifelong Learning in Europe, 1, 53.

Schibany, A. - Streicher, G. (2008): The European innovation scoreboard: Drowning by numbers? Science and Public Policy, 35, 10, 717-732.

Schillo, R. S. - Robinson, R. M. (2017): Inclusive innovation in developed countries: The who, what, why, and how. Technology Innovation Management Review, 7, 7.

Shaikin, D. - Estes, R. J. (2018): Advancing Development in Kazakhstan: The Contribution of Research and Development. Social Development Issues, 40, 2 , 36-55.

Stavbunik, Y. - Pělucha, M. (2019): The Innovation System of Kazakhstan in the Context of the Global Innovation Index. Innovation Journal, 24, 1.

Sternberg, R. J. - Lubart, T. I. 1999 The concept of creativity: Prospects and paradigms. Handbook of creativity, 1, 3-15.

Sullivan, D. - Marvel, M. (2011): How entrepreneurs' knowledge and network ties relate to the number of employees in new SMEs. Journal of Small Business Management, 49, 2, 185-206.

Suyunov, A. - Mirkasimov, B. - Karimov K. (2018): Research And Development Reform: The Case Of Kazakhstan And Uzbekistan. International Journal of Civil Service Reform and Practice, 3, 2.

Szirmai, A. - Naudé, W. - Goedhuys, M. (ed.) (2011): Entrepreneurship, innovation, and economic development. Oxford University Press.

Tang, J. - Murphy, P. J. (2012): Prior knowledge and new product and service introductions by entrepreneurial firms: The mediating role of technological innovation. Journal of Small Business Management, 50, 1, 41-62.

Tulegenova, M. (2007): Finansovyj kapital i integrirovannye struktury. 
Utepbergenov, I. - Bobrov L. - Medyankina I. (2018): Principles of creation of information support system for innovative economy in the Republic Kazakhstan. Economic and Social Development: Book of Proceedings. 271276.

Uzagalieva, A. - Kočenda, E. - Menezes, A. (2012): Technological innovation in new EU markets. Emerging Markets Finance and Trade, 48, 5, 48-65.

Varga, A. (2006): The spatial dimension of innovation and growth: Empirical research methodology and policy analysis. European Planning Studies, 14, 9, 11711186.

Zawislak, P. - Manhães Marins, L. (2007): Strenghtening Innovation in Developing Countries. Journal of Technology Management \&Innovation, 2, 4, 44-54.

Ziyadin, S. - Omarova, A. - Doszhan, R. - Saparova, G. - Zharaskyzy, G. (2018): Diversification of $\mathrm{R} \& \mathrm{D}$ results commercialization. Problems and perspectives in management, 16, 4, 331-343. 


\section{Annex A}

Table 1 Countries rate in European Scoreboard $(2008 ; 2018)$

\begin{tabular}{|c|c|c|c|}
\hline Individuals & $\begin{array}{l}\text { In } \\
\text { table }\end{array}$ & $\begin{array}{l}\text { European Scoreboard } \\
2008\end{array}$ & European Scoreboard 2018 \\
\hline Austria & 1 & Strong Innovators & Strong Innovators \\
\hline Belgium & 2 & Strong Innovators & Strong Innovators \\
\hline Bulgaria & 3 & Modest Innovators & Modest Innovators \\
\hline Cyprus & 4 & Moderate Innovators & Moderate Innovators \\
\hline $\begin{array}{l}\text { Czech } \\
\text { Republic }\end{array}$ & 5 & Moderate Innovators & Moderate Innovators \\
\hline Germany & 6 & Innovation Leaders & Strong Innovators \\
\hline Denmark & 7 & Innovation Leaders & Innovation Leaders \\
\hline Estonia & 8 & Moderate Innovators & Moderate Innovators \\
\hline Spain & 9 & Moderate Innovators & Moderate Innovators \\
\hline Finland & 10 & Innovation Leaders & Innovation Leaders \\
\hline France & 11 & Strong Innovators & Strong Innovators \\
\hline Croatia & 12 & Just moved & Moderate Innovators \\
\hline Hungary & 13 & Modest Innovators & Moderate Innovators \\
\hline Ireland & 14 & Strong Innovators & Strong Innovators \\
\hline Italy & 15 & Moderate Innovators & Moderate Innovators \\
\hline Lithuania & 16 & Modest Innovators & \Moderate Innovators \\
\hline Latvia & 17 & Modest Innovators & \Moderate Innovators \\
\hline Malta & 18 & Modest Innovators & Moderate Innovators \\
\hline Netherlands & 19 & Strong Innovators & Innovation Leaders \\
\hline Norway & 20 & Just moved & Strong Innovators \\
\hline Poland & 21 & Modest Innovators & Moderate Innovators \\
\hline Portugal & 22 & Moderate Innovators & Moderate Innovators \\
\hline Romania & 23 & Modest Innovators & Modest Innovators \\
\hline Sweden & 24 & Innovation Leaders & Innovation Leaders \\
\hline Slovenia & 25 & Moderate Innovators & Strong Innovators \\
\hline Slovakia & 26 & Modest Innovators & Moderate Innovators \\
\hline Turkey & 27 & Just moved & $\gg$ Moderate Innovators \\
\hline $\begin{array}{l}\text { United } \\
\text { Kingdom }\end{array}$ & 28 & Innovation Leaders & Innovation Leaders \\
\hline Kazakhstan & 29 & Unknown & Unknown \\
\hline
\end{tabular}

Source: own construction based on the European Innovation Scoreboards 2008, 2018 


\section{Annex B}

Figure 1 Indicator Q2 - Percentage population aged 25-34 having completed tertiary education

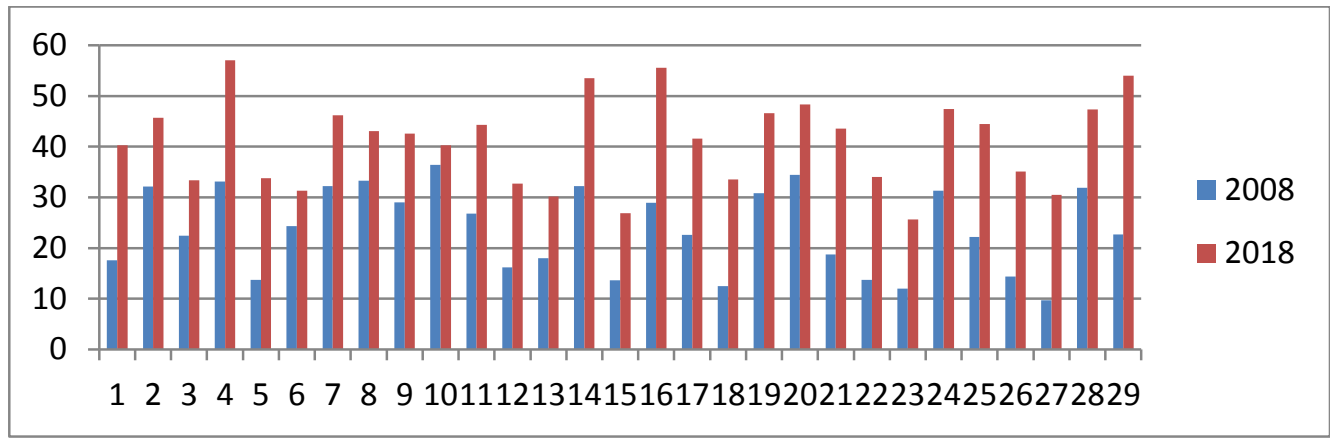

Source: own construction

Figure 2 Indicator Q3 - Lifelong learning of population from 25-64 aged

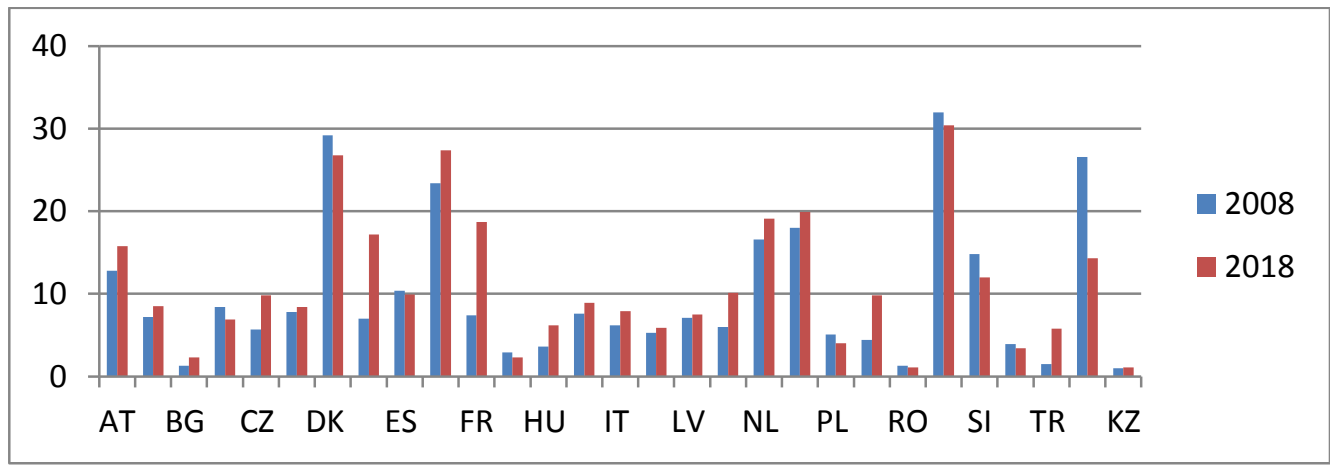

Source: own construction

Figure 3 Indicator Q5 - R\&D expenditure in the business sector (\% of GDP)

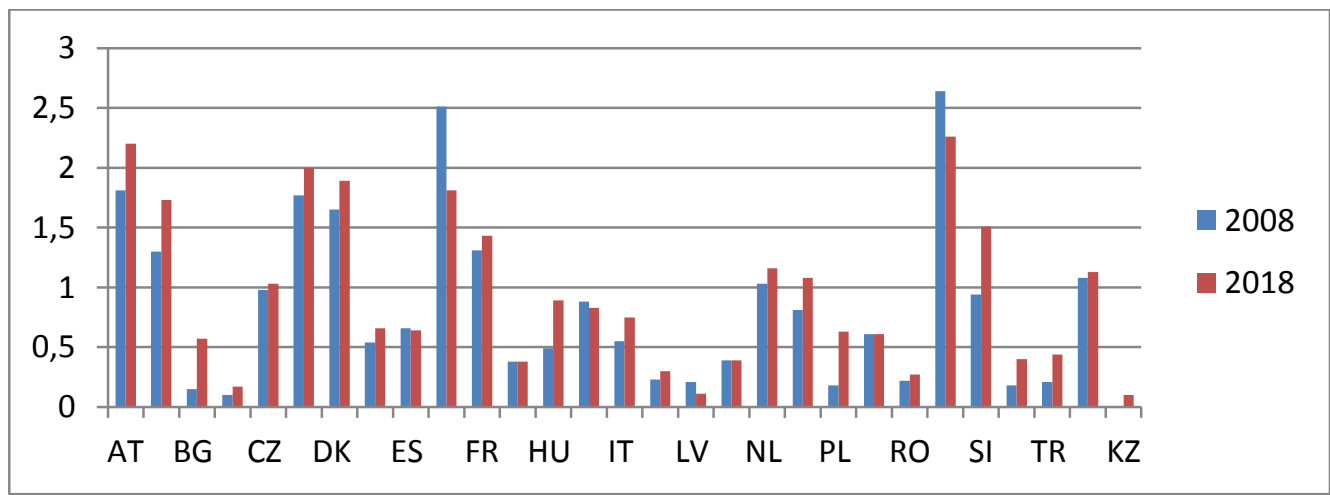

Source: own construction 
Figure 4 Indicator Q6 - Non-R\&D innovation expenditure (\% of turnover)

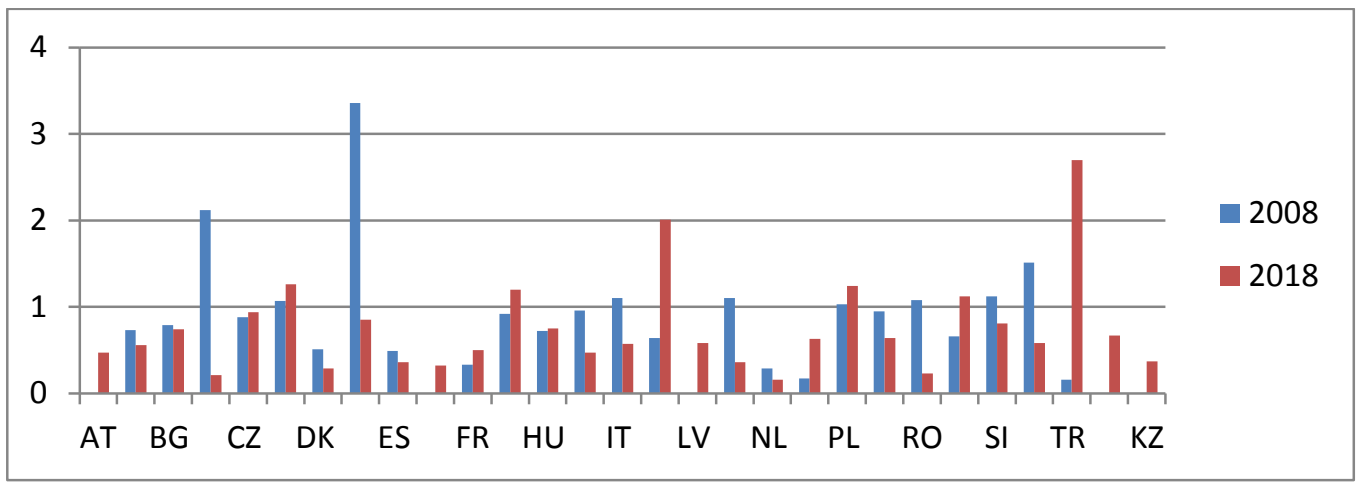

Source: own construction

Figure 5 Indicator Q7 - SMEs innovating in-house (\% of SMEs)

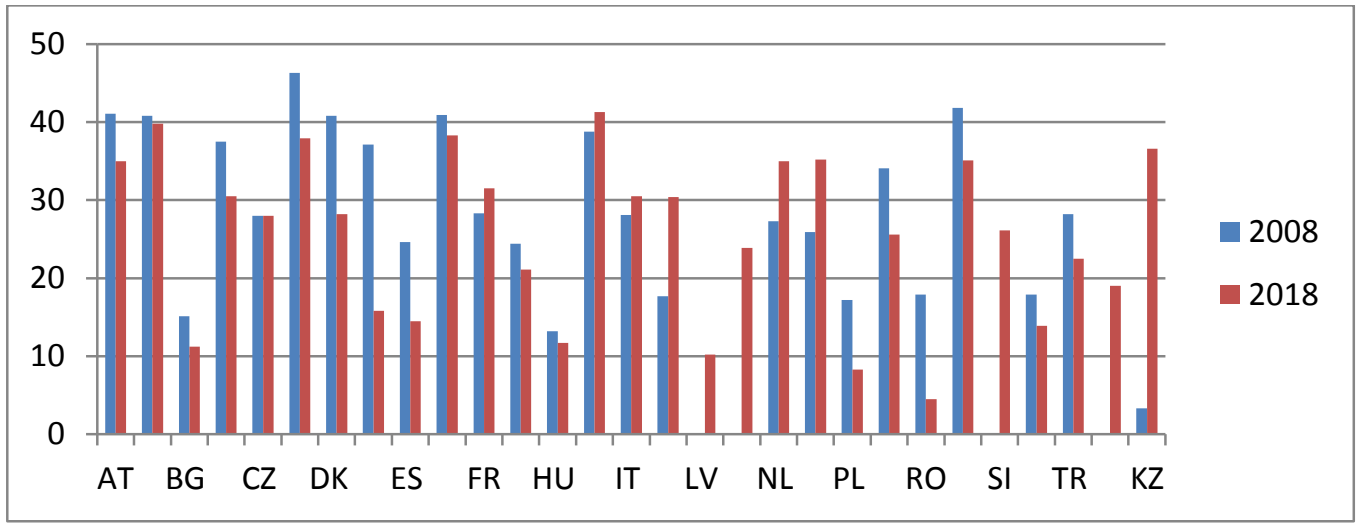

Source: own construction

Figure 6 Indicator Q8 - Innovative SMEs collaborating with others (\% of SMEs)

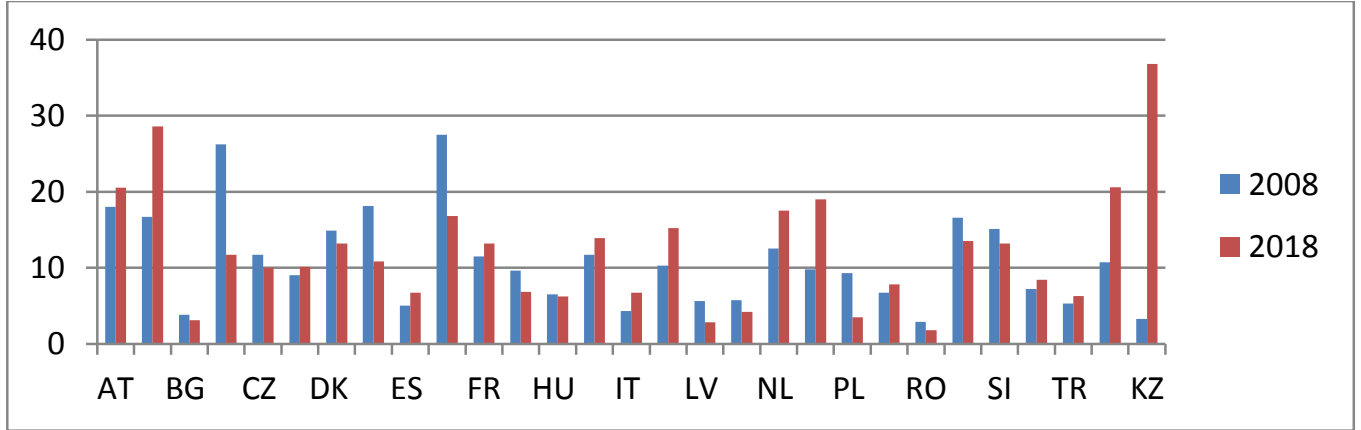

Source: own construction 
Figure 7 Indicator Q9 - Public-private co-publications per million population

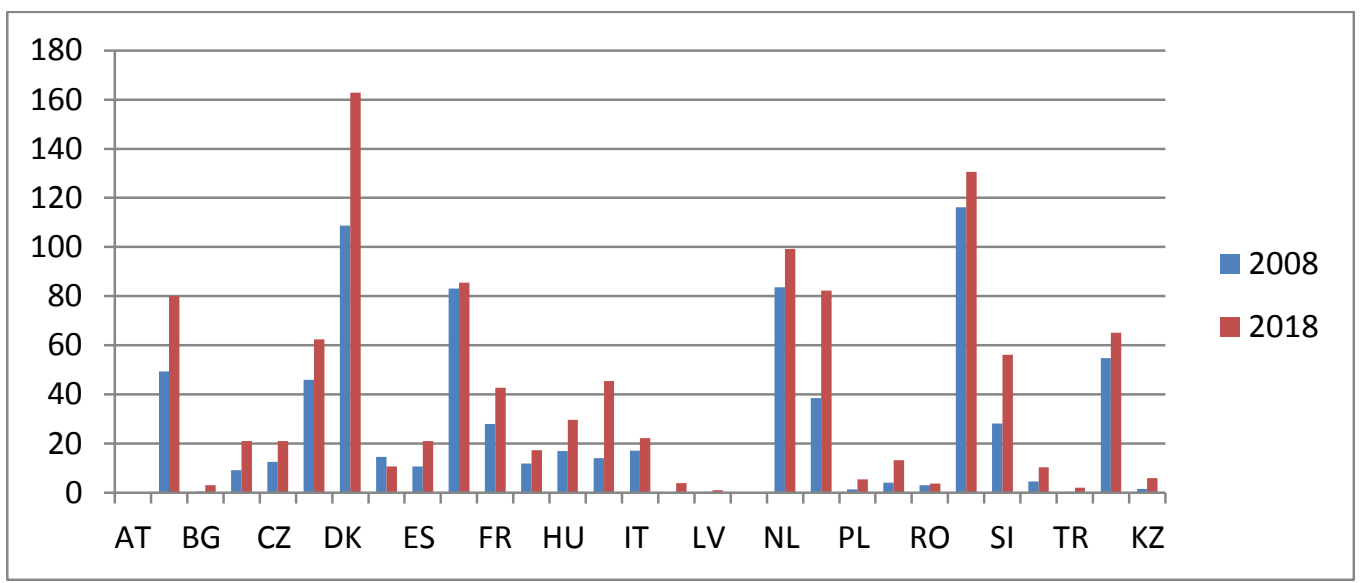

Source: own construction

Figure 8 Indicator Q11 - Trademarks applications per billion GDP in 2008 and in 2018
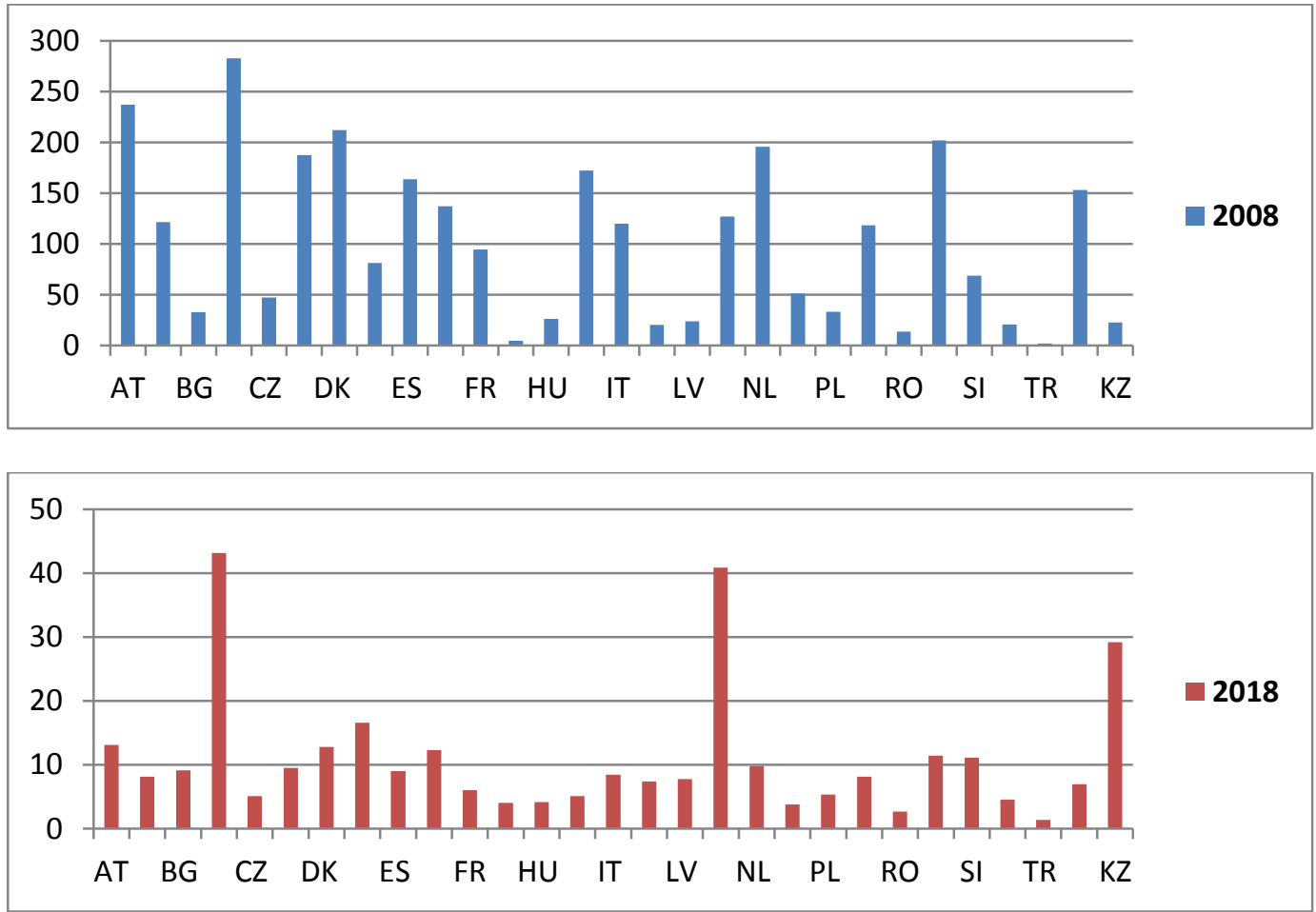

Source: own construction 
Figure 9 Indicator Q12 - Designs applications per billion GDP in 2008 and in 2018
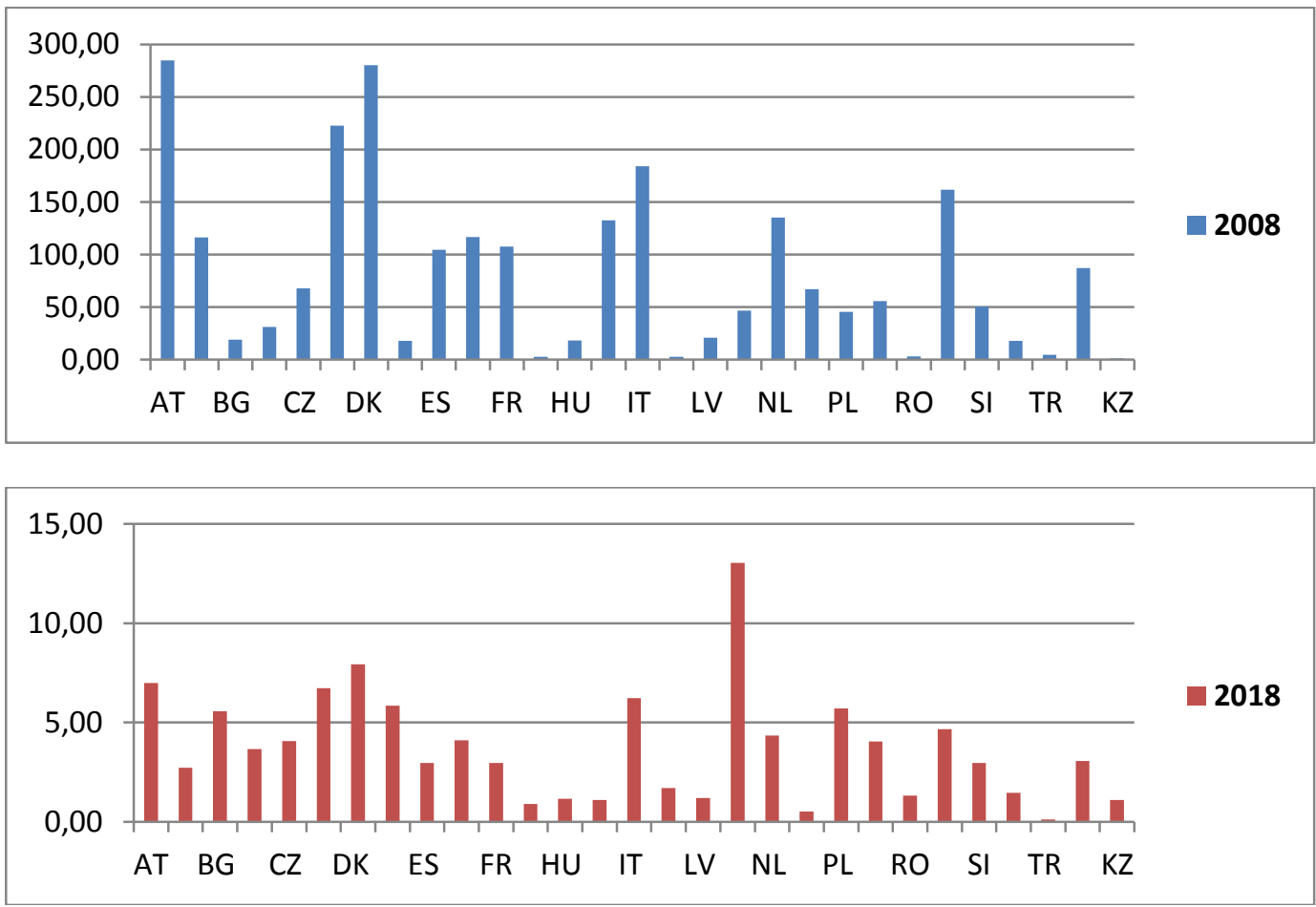

Source: own construction

Figure 10 Indicator Q13 - SMEs introducing product or process innovations (\% of SMEs)

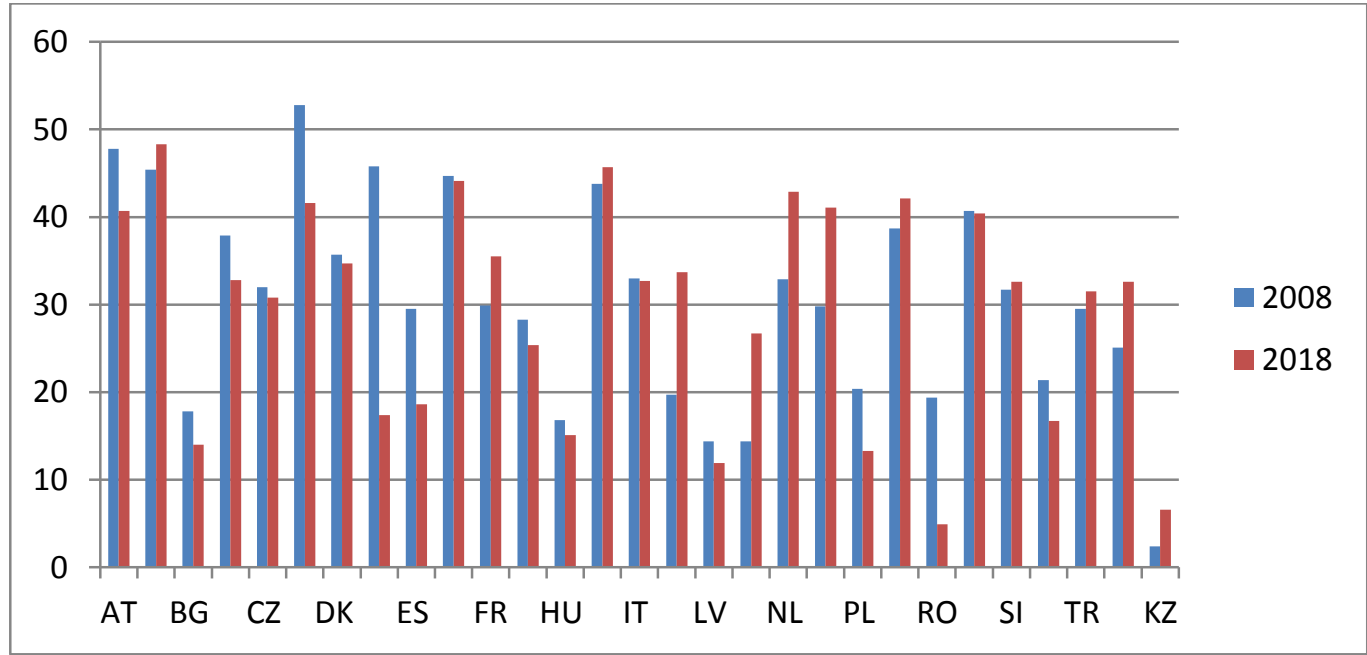

Source: own construction 
Figure 11 Indicator Q14 - SMEs introducing marketing or organizational innovations (\% of SMEs)

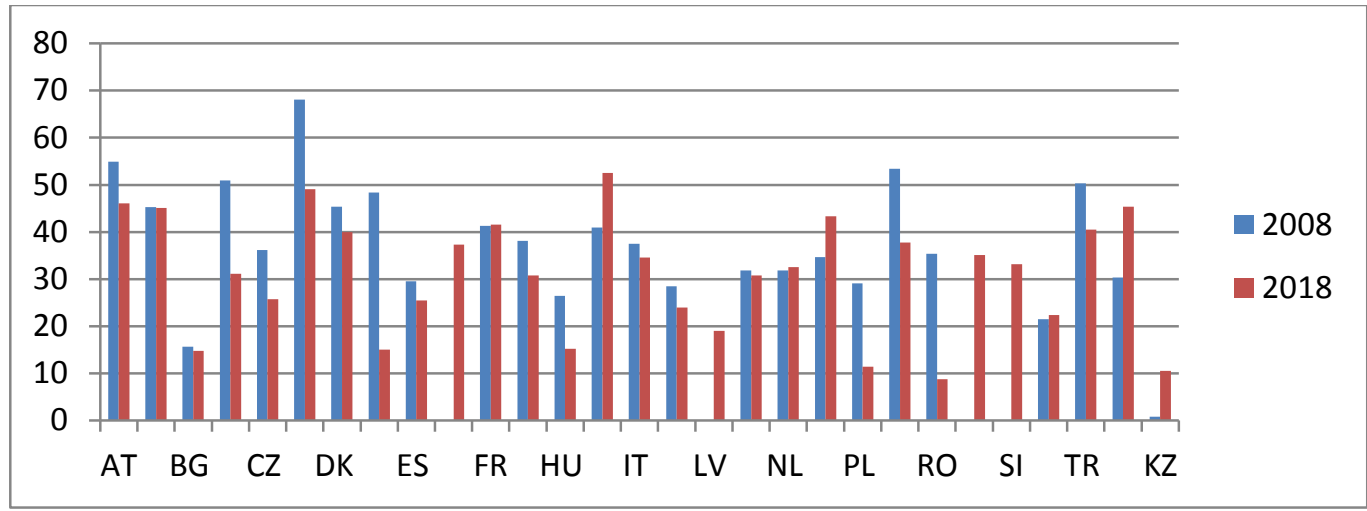

Source: own construction

Figure 12 Indicator Q15 - Employment in fast-growing enterprises in innovative sectors (\% of total employment)

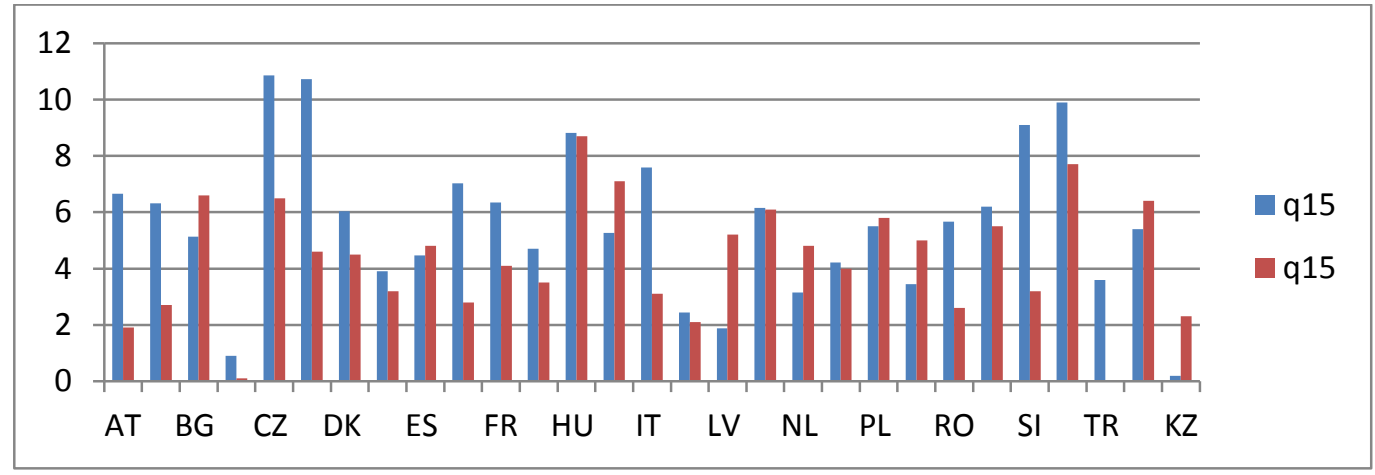

Source: own construction

Figure 13 Indicator Q16 - Employment in knowledge-intensive activities (\% of total employment)

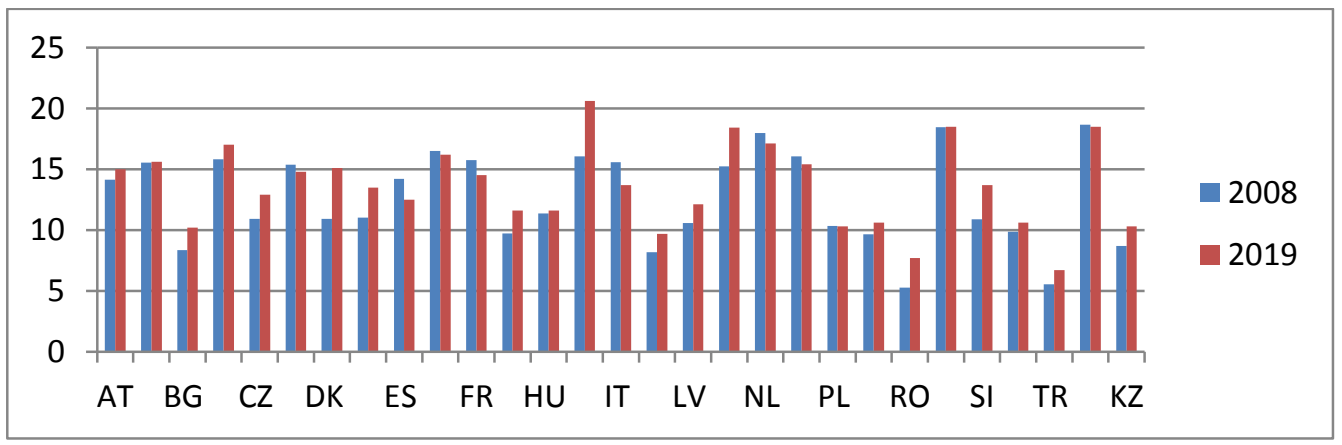

Source: own construction 
Figure 14 Indicator Q17 - Exports of medium and high-technology products as a share of total product export

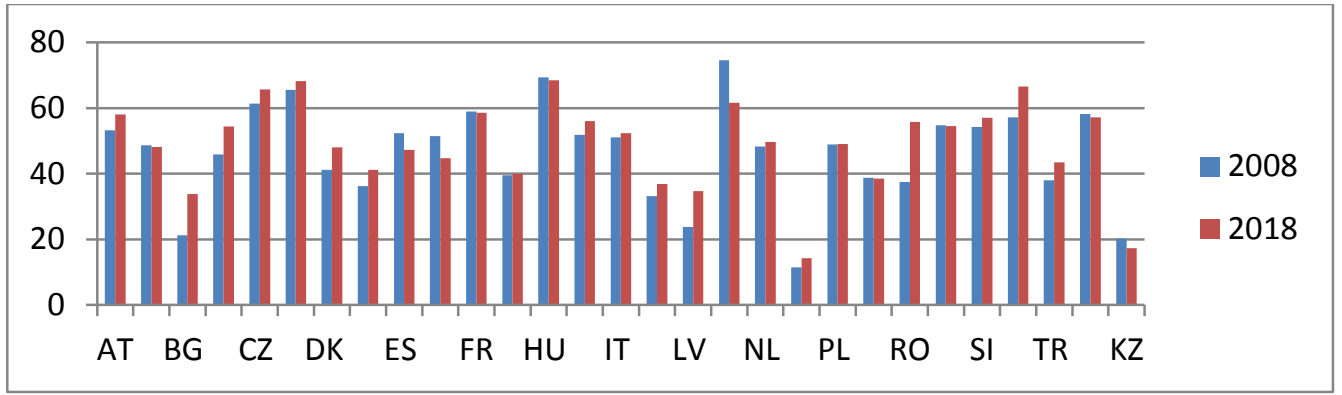

Source: own construction

Figure 15 Indicator Q18 - Knowledge-intensive services exports as \% of total services exports

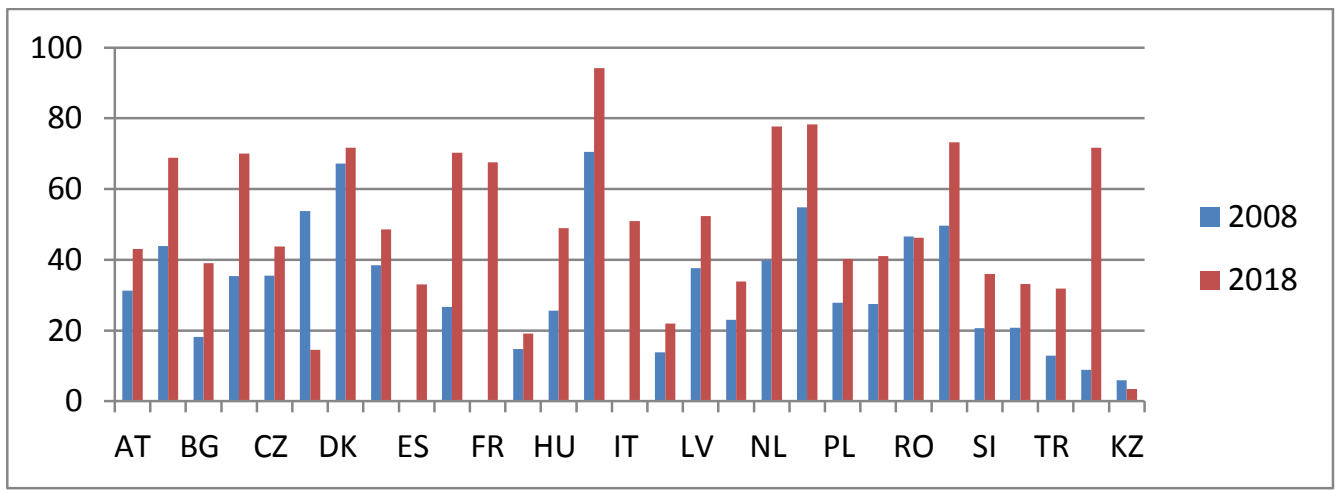

Source: own construction

Figure 16 Indicator Q19 - Sales of new-to-market and new-to-firm innovations as \% of turnover

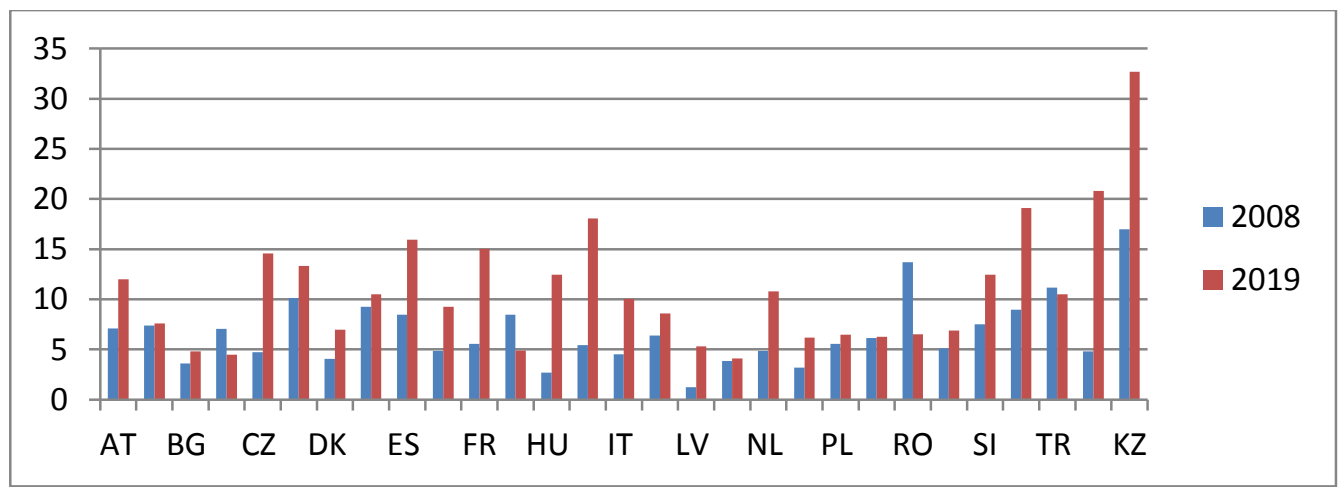

Source: own construction 


\section{Annex C}

Table 1 Harmonized Kazakh data according to the EIS in 2008

\begin{tabular}{|c|c|c|c|c|c|c|c|c|c|c|c|c|c|c|c|c|c|c|c|}
\hline & $\mathrm{q} 1$ & $\mathrm{q} 2$ & q3 & $\mathrm{q} 4$ & q5 & q6 & q7 & q8 & q9 & q10 & q11 & q12 & q13 & q14 & q15 & q16 & q17 & q18 & q19 \\
\hline AT & 1.72 & 17.6 & 12.8 & 0.75 & 1.81 & $\mathrm{n} / \mathrm{a}$ & 41.1 & 18 & 58 & 183.1 & 237.1 & 284.6 & 47.8 & 54.9 & 6.66 & 14.15 & 53.2 & 31.3 & 7.08 \\
\hline $\mathrm{BE}$ & 0.94 & 32.1 & 7.2 & 0.57 & 1.3 & 0.73 & 40.8 & 16.7 & 49.4 & 129.1 & 121.4 & 116.2 & 45.4 & 45.3 & 6.31 & 15.54 & 48.7 & 43.9 & 7.39 \\
\hline $\mathrm{BG}$ & 0.36 & 22.4 & 1.3 & 0.33 & 0.15 & 0.79 & 15.1 & 3.8 & 0.5 & 1.4 & 32.8 & 19.2 & 17.8 & 15.7 & 5.13 & 8.35 & 21.2 & 18.2 & 3.59 \\
\hline $\mathrm{CY}$ & 0.22 & 33.1 & 8.4 & 0.31 & 0.1 & 2.12 & 37.5 & 26.2 & 9.1 & 17 & 282.8 & 31.2 & 37.9 & 50.9 & 0.9 & 15.8 & 45.9 & 35.4 & 7.04 \\
\hline $\mathrm{CZ}$ & 0.86 & 13.7 & 5.7 & 0.55 & 0.98 & 0.88 & 28 & 11.7 & 12.6 & 7.3 & 47.1 & 67.7 & 32 & 36.2 & 10.85 & 10.92 & 61.3 & 35.5 & 4.72 \\
\hline $\mathrm{DE}$ & 1.56 & 24.3 & 7.8 & 0.76 & 1.77 & 1.07 & 46.3 & 9 & 45.9 & 275 & 187.7 & 222.6 & 52.8 & 68.1 & 10.72 & 15.37 & 65.5 & 53.8 & 10.11 \\
\hline DK & 0.93 & 32.2 & 29.2 & 0.88 & 1.65 & 0.51 & 40.8 & 14.9 & 108.7 & 174.6 & 212.1 & 280.4 & 35.7 & 45.4 & 6.03 & 10.92 & 41.2 & 67.2 & 4.05 \\
\hline $\mathrm{EE}$ & 0.57 & 33.3 & 7 & 0.58 & 0.54 & 3.36 & 37.1 & 18.1 & 14.5 & 5.6 & 81.4 & 17.9 & 45.8 & 48.4 & 3.9 & 11.01 & 36.2 & 38.5 & 9.27 \\
\hline $\mathrm{ES}$ & 0.67 & 29 & 10.4 & 0.55 & 0.66 & 0.49 & 24.6 & 5 & 10.6 & 29.3 & 163.8 & 104.5 & 29.5 & 29.5 & 4.47 & 14.22 & 52.3 & $\mathrm{n} / \mathrm{a}$ & 8.48 \\
\hline FI & 2.17 & 36.4 & 23.4 & 0.94 & 2.51 & $\mathrm{n} / \mathrm{a}$ & 40.9 & 27.5 & 83.1 & 267.6 & 137.3 & 116.8 & 44.7 & $\mathrm{n} / \mathrm{a}$ & 7.03 & 16.49 & 51.5 & 26.7 & 4.83 \\
\hline FR & 1.13 & 26.8 & 7.4 & 0.74 & 1.31 & 0.33 & 28.3 & 11.5 & 27.9 & 119.2 & 94.4 & 107.5 & 29.9 & 41.3 & 6.35 & 15.76 & 58.9 & $\mathrm{n} / \mathrm{a}$ & 5.56 \\
\hline HR & 0.47 & 16.2 & 2.9 & 0.55 & 0.38 & 0.92 & 24.4 & 9.6 & 11.9 & 5 & 4.5 & 2.9 & 28.3 & 38.1 & 4.7 & 9.71 & 39.5 & 14.8 & 8.45 \\
\hline $\mathrm{HU}$ & 0.42 & 18 & 3.6 & 0.46 & 0.49 & 0.72 & 13.2 & 6.5 & 16.9 & 7.8 & 26 & 18.3 & 16.8 & 26.4 & 8.82 & 11.35 & 69.3 & 25.6 & 2.7 \\
\hline IE & 1.11 & 32.2 & 7.6 & 0.44 & 0.88 & 0.96 & 38.8 & 11.7 & 14 & 64.1 & 172.5 & 132.7 & 43.8 & 40.9 & 5.26 & 16.05 & 51.8 & 70.5 & 5.43 \\
\hline IT & 0.89 & 13.6 & 6.2 & 0.52 & 0.55 & 1.1 & 28.1 & 4.3 & 17.2 & 76.1 & 120 & 184.2 & 33 & 37.5 & 7.59 & 15.57 & 51.1 & $\mathrm{n} / \mathrm{a}$ & 4.52 \\
\hline LT & 0.61 & 28.9 & 5.3 & 0.58 & 0.23 & 0.64 & 17.7 & 10.3 & 0 & 1.3 & 20.4 & 2.6 & 19.7 & 28.5 & 2.44 & 8.19 & 33.1 & 13.8 & 6.39 \\
\hline LV & 0.24 & 22.6 & 7.1 & 0.42 & 0.21 & $\mathrm{n} / \mathrm{a}$ & $\mathrm{n} / \mathrm{a}$ & 5.6 & 0.4 & 5.7 & 23.7 & 21 & 14.4 & $\mathrm{n} / \mathrm{a}$ & 1.88 & 10.57 & 23.8 & 37.6 & 1.25 \\
\hline MT & 0.03 & 12.5 & 6 & 0.21 & 0.39 & 1.1 & $\mathrm{n} / \mathrm{a}$ & 5.7 & 0 & 21.6 & 127.1 & 46.7 & 14.4 & 31.8 & 6.16 & 15.22 & 74.5 & 23 & 3.85 \\
\hline NL & 0.87 & 30.8 & 16.6 & 0.67 & 1.03 & 0.29 & 27.3 & 12.5 & 83.7 & 173.3 & 195.8 & 135.3 & 32.9 & 31.8 & 3.15 & 17.97 & 48.3 & 39.9 & 4.87 \\
\hline $\mathrm{NO}$ & 0.94 & 34.4 & 18 & 0.77 & 0.81 & 0.17 & 25.9 & 9.8 & 38.5 & 95.5 & 51.2 & 67.1 & 29.8 & 34.7 & 4.21 & 16.05 & 11.4 & 54.8 & 3.17 \\
\hline PL & 0.86 & 18.7 & 5.1 & 0.38 & 0.18 & 1.03 & 17.2 & 9.3 & 1.3 & 3 & 33.2 & 45.5 & 20.4 & 29.1 & 5.5 & 10.33 & 48.9 & 27.9 & 5.55 \\
\hline PT & 2.75 & 13.7 & 4.4 & 0.46 & 0.61 & 0.95 & 34.1 & 6.7 & 4 & 7.4 & 118.5 & 55.8 & 38.7 & 53.4 & 3.45 & 9.65 & 38.7 & 27.5 & 6.12 \\
\hline $\mathrm{RO}$ & 0.48 & 12 & 1.3 & 0.31 & 0.22 & 1.08 & 17.9 & 2.9 & 3.1 & 0.7 & 13.5 & 3 & 19.4 & 35.4 & 5.66 & 5.26 & 37.5 & 46.6 & 13.69 \\
\hline $\mathrm{SE}$ & 2.25 & 31.3 & 32 & 0.99 & 2.64 & 0.66 & 41.8 & 16.6 & 116.1 & 184.8 & 201.9 & 161.9 & 40.7 & $\mathrm{n} / \mathrm{a}$ & 6.2 & 18.45 & 54.8 & 49.7 & 5.1 \\
\hline SI & 0.96 & 22.2 & 14.8 & 0.6 & 0.94 & 1.12 & $\mathrm{n} / \mathrm{a}$ & 15.1 & 28.2 & 32.2 & 68.7 & 50.5 & 31.7 & $\mathrm{n} / \mathrm{a}$ & 9.09 & 10.89 & 54.2 & 20.7 & 7.5 \\
\hline SK & 0.89 & 14.4 & 3.9 & 0.27 & 0.18 & 1.51 & 17.9 & 7.2 & 4.5 & 5.8 & 20.6 & 18 & 21.4 & 21.5 & 9.89 & 9.86 & 57.2 & 20.8 & 8.95 \\
\hline TR & 0.12 & 9.7 & 1.5 & 0.37 & 0.21 & 0.16 & 28.2 & 5.3 & 0.3 & 1 & 1.9 & 4.5 & 29.5 & 50.3 & 3.6 & 5.53 & 38 & 12.9 & 11.17 \\
\hline UK & 1.61 & 31.9 & 26.6 & 0.64 & 1.08 & $\mathrm{n} / \mathrm{a}$ & $\mathrm{n} / \mathrm{a}$ & 10.7 & 54.7 & 91.4 & 153.1 & 87.1 & 25.1 & 30.3 & 5.4 & 18.64 & 58.2 & 8.9 & 4.81 \\
\hline $\mathrm{KZ}$ & 0.07 & 22.7 & 1 & 0.22 & 0.23 & 0.002 & 3.1 & 3.3 & 1.6 & 11.3 & 22.6 & 1.1 & 2.4 & 0.8 & 0.19 & 8.7 & 20.2 & 5.94 & 17 \\
\hline
\end{tabular}

Source: own construction based on the EIS 2008 
Table 2 Harmonized Kazakh data according to the EIS in 2018

\begin{tabular}{|c|c|c|c|c|c|c|c|c|c|c|c|c|c|c|c|c|c|c|c|}
\hline & $\mathrm{q} 1$ & $\mathrm{q} 2$ & q3 & $\mathrm{q} 4$ & q5 & q6 & q7 & $\mathrm{q} 8$ & q9 & $\mathrm{q} 10$ & q11 & $\mathrm{q} 12$ & $\mathrm{q} 13$ & $\mathrm{q} 14$ & q15 & q16 & $\mathrm{q} 17$ & $\mathrm{q} 18$ & q19 \\
\hline AT & 1.9 & 40.3 & 15.8 & 0.87 & 2.2 & 0.47 & 35 & 20.5 & 82.3 & 4.7 & 13.0 & 6.98 & 40.7 & 46.1 & 1.9 & 15 & 58 & 43.1 & 11.9 \\
\hline $\mathrm{BE}$ & 1.9 & 45.7 & 8.5 & 0.74 & 1.73 & 0.56 & 39.8 & 28.6 & 80 & 3.16 & 8.11 & 2.72 & 48.3 & 45.1 & 2.7 & 15.6 & 48.2 & 68.9 & 7.6 \\
\hline BG & 1.5 & 33.4 & 2.3 & 0.21 & 0.57 & 0.74 & 11.2 & 3.1 & 3 & 0.64 & 9.1 & 5.56 & 14 & 14.8 & 6.6 & 10.2 & 33.8 & 39 & 4.8 \\
\hline $\mathrm{CY}$ & 0.6 & 57 & 6.9 & 0.27 & 0.17 & 0.21 & 30.5 & 11.7 & 21.1 & 0.82 & 43.1 & 3.67 & 32.8 & 31.1 & 0.1 & 17 & 54.4 & 70 & 4.49 \\
\hline $\mathrm{CZ}$ & 1.7 & 33.8 & 9.8 & 0.64 & 1.03 & 0.94 & 28 & 10 & 21 & 0.93 & 5.09 & 4.07 & 30.8 & 25.7 & 6.5 & 12.9 & 65.7 & 43.8 & 14.5 \\
\hline $\mathrm{DE}$ & 2.8 & 31.3 & 8.4 & 0.94 & 2 & 1.26 & 37.9 & 10.1 & 62.4 & 6.11 & 9.51 & 6.72 & 41.6 & 49.1 & 4.6 & 14.8 & 68.2 & 14.6 & 13.3 \\
\hline DK & 3.2 & 46.2 & 26.8 & 0.97 & 1.89 & 0.29 & 28.2 & 13.2 & 162. & 6.05 & 12.7 & 7.94 & 34.7 & 40 & 4.5 & 15.1 & 48 & 71.7 & 6.96 \\
\hline $\mathrm{EE}$ & 1.1 & 43.1 & 17.2 & 0.61 & 0.66 & 0.85 & 15.8 & 10.8 & 10.6 & 1.01 & 16.5 & 5.84 & 17.4 & 15 & 3.2 & 13.5 & 41.2 & 48.6 & 10.4 \\
\hline ES & 2.6 & 42.6 & 9.9 & 0.55 & 0.64 & 0.36 & 14.5 & 6.7 & 21.1 & 1.45 & 8.99 & 2.97 & 18.6 & 25.5 & 4.8 & 12.5 & 47.2 & 33.1 & 15.9 \\
\hline FI & 2.9 & 40.3 & 27.4 & 0.91 & 1.81 & 0.32 & 38.3 & 16.8 & 85.4 & 7.43 & 12.3 & 4.11 & 44.1 & 37.3 & 2.8 & 16.2 & 44.7 & 70.3 & 9.27 \\
\hline FR & 1.7 & 44.3 & 18.7 & 0.78 & 1.43 & 0.5 & 31.5 & 13.2 & 42.8 & 3.98 & 6.04 & 2.96 & 35.5 & 41.6 & 4.1 & 14.5 & 58.5 & 67.6 & 15.0 \\
\hline HR & 1.2 & 32.7 & 2.3 & 0.46 & 0.38 & 1.2 & 21.1 & 6.8 & 17.3 & 0.61 & 4 & 0.9 & 25.4 & 30.8 & 3.5 & 11.6 & 39.9 & 19.1 & 4.91 \\
\hline $\mathrm{HU}$ & 1 & 30.2 & 6.2 & 0.29 & 0.89 & 0.75 & 11.7 & 6.2 & 29.6 & 1.34 & 4.15 & 1.15 & 15.1 & 15.2 & 8.7 & 11.6 & 68.5 & 49 & 12.4 \\
\hline IE & 2.6 & 53.5 & 8.9 & 0.35 & 0.83 & 0.47 & 41.3 & 13.9 & 45.4 & 1.8 & 5.08 & 1.09 & 45.7 & 52.5 & 7.1 & 20.6 & 56 & 94.2 & 18.0 \\
\hline IT & 1.5 & 26.9 & 7.9 & 0.5 & 0.75 & 0.57 & 30.5 & 6.7 & 22.2 & 2.16 & 8.46 & 6.23 & 32.7 & 34.6 & 3.1 & 13.7 & 52.4 & 50.9 & 10.0 \\
\hline LT & 0.9 & 55.6 & 5.9 & 0.55 & 0.3 & 2.01 & 30.4 & 15.2 & 3.9 & 0.81 & 7.39 & 1.71 & 33.7 & 24 & 2.1 & 9.7 & 36.9 & 22 & 8.57 \\
\hline LV & 0.7 & 41.6 & 7.5 & 0.33 & 0.11 & 0.58 & 10.2 & 2.8 & 1 & 0.82 & 7.77 & 1.2 & 11.9 & 19 & 5.2 & 12.1 & 34.7 & 52.4 & 5.31 \\
\hline MT & 0.7 & 33.5 & 10.1 & 0.23 & 0.39 & 0.36 & 23.9 & 4.2 & 0 & 1.31 & 40.8 & 13.0 & 26.7 & 30.8 & 6.1 & 18.4 & 61.6 & 33.9 & 4.12 \\
\hline NL & 2.4 & 46.6 & 19.1 & 0.87 & 1.16 & 0.16 & 35 & 17.5 & 99.3 & 5.82 & 9.78 & 4.34 & 42.9 & 32.5 & 4.8 & 17.1 & 49.7 & 77.7 & 10.8 \\
\hline $\mathrm{NO}$ & 2 & 48.3 & 19.9 & 0.95 & 1.08 & 0.63 & 35.2 & 19 & 82.2 & 2.66 & 3.79 & 0.52 & 41.1 & 43.3 & 4 & 15.4 & 14.3 & 78.3 & 6.16 \\
\hline PL & 0.6 & 43.6 & 4 & 0.32 & 0.63 & 1.24 & 8.3 & 3.5 & 5.4 & 0.69 & 5.33 & 5.71 & 13.3 & 11.4 & 5.8 & 10.3 & 49 & 40.2 & 6.45 \\
\hline PT & 1.9 & 34 & 9.8 & 0.64 & 0.61 & 0.64 & 25.6 & 7.8 & 13.2 & 0.95 & 8.1 & 4.04 & 42.1 & 37.8 & 5 & 10.6 & 38.5 & 41.1 & 6.27 \\
\hline $\mathrm{RO}$ & 0.8 & 25.6 & 1.1 & 0.21 & 0.27 & 0.23 & 4.5 & 1.8 & 3.7 & 0.22 & 2.64 & 1.31 & 4.9 & 8.8 & 2.6 & 7.7 & 55.8 & 46.2 & 6.51 \\
\hline SE & 2.7 & 47.4 & 30.4 & 0.98 & 2.26 & 1.12 & 35.1 & 13.5 & 130. & 9.08 & 11.4 & 4.67 & 40.4 & 35.1 & 5.5 & 18.5 & 54.5 & 73.2 & 6.89 \\
\hline SI & 3.5 & 44.5 & 12 & 0.49 & 1.51 & 0.81 & 26.1 & 13.2 & 56.1 & 1.65 & 11.0 & 2.97 & 32.6 & 33.2 & 3.2 & 13.7 & 57 & 36 & 12.4 \\
\hline SK & 2.2 & 35.1 & 3.4 & 0.39 & 0.4 & 0.58 & 13.9 & 8.4 & 10.3 & 0.51 & 4.49 & 1.46 & 16.7 & 22.4 & 7.7 & 10.6 & 66.5 & 33.2 & 19.1 \\
\hline TR & 0.4 & 30.5 & 5.8 & 0.44 & 0.44 & 2.7 & 22.5 & 6.3 & 2 & 0.73 & 1.34 & 0.11 & 31.5 & 40.5 & $\mathrm{n} / \mathrm{a}$ & 6.7 & 43.4 & 31.9 & 10.5 \\
\hline UK & 3.1 & 47.3 & 14.3 & 0.52 & 1.13 & 0.67 & 19 & 20.6 & 65.1 & 3.06 & 6.95 & 3.07 & 32.6 & 45.4 & 6.4 & 18.5 & 57.1 & 71.7 & 20.8 \\
\hline $\mathrm{KZ}$ & 0.3 & 53.9 & 1.1 & 0.25 & 0.1 & 0.37 & 36.6 & 36.8 & 5.9 & 7.1 & 29.2 & 1.1 & 6.6 & 10.5 & 2.3 & 10.3 & 17.3 & 3.5 & 32.7 \\
\hline
\end{tabular}

Source: own construction based on the EIS 2018 